\title{
Edsel Ford: The Businessman as Artist
}

A Wealth of Creative Abilities

\section{John Dean}

\section{(2) OpenEdition}

Journals

Electronic version

URL: https://journals.openedition.org/transatlantica/5175

DOI: $10.4000 /$ transatlantica. 5175

ISSN: 1765-2766

\section{Publisher}

Association française d'Etudes Américaines (AFEA)

\section{Electronic reference}

John Dean, "Edsel Ford: The Businessman as Artist", Transatlantica [Online], 2 | 2010, Online since 15 April 2011, connection on 01 February 2023. URL: http://journals.openedition.org/transatlantica/5175 ; DOI: https://doi.org/10.4000/transatlantica.5175

This text was automatically generated on 1 February 2023.

\section{(c)}

Creative Commons - Attribution-NonCommercial-NoDerivatives 4.0 International - CC BY-NC-ND 4.0 https://creativecommons.org/licenses/by-nc-nd/4.0/ 


\title{
Edsel Ford: The Businessman as
}

\section{Artist}

\author{
A Wealth of Creative Abilities
}

John Dean

1 This essay's objective is to examine an overlooked, outstanding example of the businessman as artist, Edsel Bryant Ford. To consider his skill as automobile designer; his forceful, innovative management of advertising and public relations; his adept painting, sculpting and photography; his exceptional sense of personal elegance; the creation by his wife and himself of a remarkable personal residence; his philanthropic enterprises; his challenging, adroit and often deeply frustrating dealings with his own father Henry Ford; and, last but not least, his use of Diego Rivera-a man strangely misunderstood in his own time as the artist who did not do business.

Edsel Ford's life story happened in a unique American city, Detroit, Michigan, which the late New York Times journalist R. W. Apple almost perfectly labelled as "a city built on four wheels and a full tank." So Detroit itself needs to be explained as well in order to place the text of the man in the context of his environment. Altogether this brief critical sortie can only begin to explore the vast territory covered by Edsel Ford, his times, his city and the extraordinary issues with which this man and his environment were involved-to open doors on vast libraries and disappearing archives of information, to offer an analysis of materials and questions that are still in their relatively early stages of national cultural history and international public awareness.

This essay seeks to move to an analytical culmination of men and elements which were different yet similar: Edsel Ford, Diego Rivera, and the material and spiritual nature of the Detroit Industry Murals. All of which brilliantly combined in the special conditions of the early American Great Depression years and the new-born Goliath of Detroit. This city was then America's most overheated cauldron of economic, social, and cultural health and sudden illness brought on by the nation's worst economic crisis to date. Edsel Ford's life story happened in a spectacular period of American boom, bust, and boom again. It will be told in part by order of the people, the place, the problem, and its solution. Character is fate. It can also be national identity. Specially when enormous 
fortunes, ambitions, needs and opportunities are involved with conflicting currents of achievements and disasters. Which is what happened here.

4 Edsel Bryant Ford (1893-1943) was the only child of Clara Bryant Ford and Henry Ford. He was born in Detroit, Michigan, when it was known as the "City Beautiful" famed for its shaded boulevards lush with enormous elm, maple and chestnut trees and its large frame houses painted white or dark green that glistened in the bright air and bracing winds blowing in off the Great Lakes. It was a time when horses, buggies, prosperous pedestrians, playful children, colorful street vendors, private carriages and bicycles ruled the streets. In 1893 the first electric streetcar clanged its way down wide Woodward Avenue out to Bloomfield Hills and Pontiac, Michigan. And then came the horseless carriages. ${ }^{2}$

5 In the United States back then Charles Brady King and Henry Ford in Detroit, Ransom E. Olds in Lansing, Michigan, Duryea Motor Wagon Company in Springfield, Massachusetts, The Franklin Car Company in Syracuse, New York, The Mitchell-Lewis Company in Racine, Wisconsin, The Willys-Overland Company in Toledo, Ohio, The Pullman Automobile built by the York Motor Company in York, Pennsylvania, and many other businesses in Michigan and nation wide began creating and tinkering with these newfangled mechanical wonders. The automobile's development in and around Detroit soon seemed to take on a gigantic momentum of its own. In the twentieth century about 3,000 different automobile nameplates would be sold in the United States. Most of these were made by American producers selling their goods prior to 1950. It was a time and a place, a way that was and is no more.

6 At the start of this business nobody came close to Michigan and Ford. By 1918 half of the world's cars were Ford Model Ts. By 1939 the state was the home to $63.9 \%$ of all wage earners in the automotive industry. ${ }^{3}$ Other car companies came and went. Like Britain, France, and Germany in Europe, in the car industry people soon recognized Detroit's Big Three-GM, Ford, and Chrysler as the giants. Each seemed nations in and of themselves. Ford descended from first place in the 1920s but never lost its prominence or essential prosperity. Ford remained the salient "universal car" as automobility shaped America and as the United States became a nation of individuals on wheels.

7 In 1900 the USA had about two thousand automobiles, less than ten miles of paved concrete road, and twenty million horses. In 2000 the USA had an estimated two-fifths of all passenger cars in the world, over two hundred and twenty one million registered motor vehicles (more vehicles than licensed drivers) - with figures rising yearly by the millions ${ }^{4}$-and a lot fewer horses. Life changed. Mobility ruled. The car became as ordinary and international as TV, tourism or teenagers.

Once the hub of the new wheel was this City on the Straits-le Détroit, so named by Antoine de la Mothe Cadillac when he founded the city as a French trading post in 1701. The people and the place showed a genius for adapting to different times and markets. Edsel Ford grew up with Detroit as it passed from its state of serenity and bucolic charm to become the automobile's cradle of creativity, its smoky seedbed of mass 
production, and its world capital without rival-with his family's company at the cutting edge. ${ }^{5}$

\section{II} generation. He was president and design director of Ford Motor Company for twentyfive years (1919-1943) and without his cool guidance, firm common sense and loyalty it might not have survived. The young US movie industry of the time was speckled with Edsel Ford figures such as actors Wallace Reid (1890-1923) and Douglas Fairbanks (1883-1939). It was a type of man who was essentially urban, and who ingeniously coped with America's big city problems and its new inventions which made them prosperous. He was a type of man who steadfastly maintained a full set of morals and proprieties while he lived his life as a cheerful swashbuckler in constant high gear. ${ }^{6}$

Off the record in the 1920s this portrait was reinforced by a Ford Motor Company inhouse biography of Edsel Ford whose style bears all the hall marks of the oratorical flourishes of Ford Motor Company spokesman William John Cameron (1878-1955) and possibly Samuel Crowther (1878-1955). Most likely this encomium was written around the time Edsel Ford became company president. Never released for public consumption, this biography is redolent with the sentimental optimism of Victorian poetry and Arthurian idealism, a very romantic reading of an industrial crown prince's enthronement. Which brazenly declared: "In 1912, when Edsel Ford was nineteen years of age, he completed his course in the University School and began his personal connection with the gigantic concern which is his twin brother, or better still, is his sword ex-calibre, forged by his father, with which if he be strong enough, he shall achieve great deeds." A romantic narrative was the proffered model of his achievement.

But great deeds according to whose wishes and how? Edsel Ford did not like the limelight. He was a man camouflaged by his own creations, the chance blunders of history, a person of few words and much action, a duke of dark corners. One may rightly say about Edsel Ford what US historian William Leuchtenburg noted about Franklin Delano Roosevelt and John F. Kennedy at their best: "Each had an upper-class education, found a life of public service more attractive than money-grabbing, and each had a respect for the decencies. At heart, too, each had a kind of patrician reticence, an impervious private dignity."

In comparison with Roosevelt and Kennedy what is perhaps difficult for the contemporary reader to accept or understand here about certain business people of Edsel Ford's generation (for he was actually not born into great wealth) is the belief and practice-still common among his contemporaneous entrepreneurial businessmen like Detroit's James Couzens (1872-1936) or Henry Leland (1843-1932) -that a business was a public trust in which the owner had a patriarchal responsibility to one's community. Business was the art of social concern. ${ }^{9}$ In the generation prior to Edsel Ford's in Detroit this trait was potently evident in ex-shoe salesman and eventual owner of Pingree and Smith Shoe Co., the US West's largest shoe manufacturing concern, Detroit's progressive mayor Hazen S. Pingree (1840-1901). ${ }^{10}$ The mystery of Edsel Ford the man was greatly a matter of his birthright. As fate would have it, he was the son of the great entrepreneur Henry Ford who turned Ford into a 
brand name which still flourishes and is still mainly controlled by the same family since it was founded more than a century ago in 1903.

Like Jesus Christ in his Sermon on the Mount, Henry Ford had declared in 1907: "I will build a motor car for the great multitude. It will be large enough for the family but small enough for the individual to run and care for. It will be constructed of the best materials, by the best men to be hired, after the simplest designs that modern engineering can devise. But it will be so low in price that no man making a good salary will be unable to own one-and enjoy with his family the blessing of hours of pleasure in God's great open spaces." ${ }^{11}$ And he did it.

of course Henry Ford didn't do it alone. But to most Americans of the time the accomplishment looked that way-reinforced by Ford Motor Company's advertising. His cars were initially sold as certified because they were "mechanical triumphs" tested and "driven by Mr. Ford". ${ }^{12}$ For "The Ford Model $\mathrm{T}$ is a Popular Car"-Ford ad copy ran in 1909-because the "Ford car part against part, feature against feature, design against design, material against material" beats all others. And by 1925 Ford ads proudly proclaimed (one in particular that captioned a picture of a rural doctor coming to make his visit) that Ford was as:

Dependable As The Doctor Himself.

The dependability of the Ford car-like that of the family physician who uses it so extensively-has become almost traditional. Instinctively you place a trust in this car [...] Such universal faith is the result of Ford reliability proved over a long period of years-years in which quality has grown consistently better, while price has been steadily reduced.

For Henry Ford, truth be told, liked the look and sound of things this way. "And Mr. Ford to me was [...] like a god! He was like a god," as retired Detroit assembly line worker "Red" Cole reflected with awe about Henry Ford in a late 1980s interview. ${ }^{13}$ Red Cole's opinion pervaded America.

As with Voltaire in the age of the Enlightenment, Henry Ford in the $20^{\text {th }}$ century's modern Industrial Era meant more than the mere man himself. He was a one-of-a-kind, successful "natural" (specially through the 1920s) whose character and career nevertheless constituted in itself a prodigious, new era, a generational culture. As the Victorian biographer John Morley wrote about Voltaire, so it may be said about Henry Ford in the meteoric phase of his early career: "Many of his ideas were in the air, and did not belong to him peculiarly; but so strangely rapid and perfect was his assimilation of them, so vigorous and minutely penetrative was the quality of his understanding, so firm and independent his initiative, that even these were instantly stamped with the express image of his personality." ${ }^{14}$

A reputation is a strange thing. It's often what's seen and not what is. A reputation is a great noise, to paraphrase Napoleon, that can build, swell, remain and reach to other generations even after land, monuments and nations have fallen. To be the only child of Henry Ford was a bit like being the only child of Napoleon Bonaparte. In a popular US poll of the time, Edsel Ford's father Henry Ford was regarded as the third most important person who had ever lived-preceded by Bonaparte and Christ. And Americans still rank him as the 20th century's greatest businessman. ${ }^{15}$ While Americans who came of age after World War Two mainly know the name "Edsel" because of a failed automobile given this family name and unsuccessfully sold by Ford Motor Company from 1957-1960. What once sparkled as a diamond became dulled to a lemon. 
Ironically there's even a mountain range named after Edsel Ford, but it's in the Antarctic. ${ }^{16}$

Edsel Ford's own worth and reputation has fallen miles below his actual accomplishments. The mystery of the man is compounded of timely pressures, older principles, and unique personalities. First, it wasn't easy to come of economic age and power as he did. His family's concern was a huge business but a tight little company. Henry Ford owned an estimated 55.45\% of Ford Motor Company. Edsel Ford owned 41.65\%. And Henry Ford's wife Clara Bryant Ford owned 3\%. ${ }^{17}$ Closed circle. By the mid 1920s the automobile Fords were among the top four wealthiest people in America, worth about eleven billion dollars in today's money-in so far as the exact sums were publicly known.

There had to be father-son competition to some extent. But to what extent exactly, we shall never know. Father always held the upper hand, but that didn't mean he was better at everything. Father and son took the inner secrets of their partnership's conflicts and resolutions to their graves. Edsel Ford's own son, Henry Ford II (1917-1987) begrudged the elder Henry Ford for his relation to his father: "My grandfather killed my father in my mind. I know he died of cancer-but it was because of what my grandfather did to him." ${ }^{18}$ But this emotion obscures a rational truth. And Henry Ford II-aka "Hank the Deuce" and "Never Complain, Never Explain"-was notorious for his hot tempered judgements.

21 The all-too-human issue here is: what does a son do for a follow-up act when one's father is Henry Ford? Son-father, father-son competitive and complementary relations are issues as old as mankind. For the son it can be like the pressure of a sprout against the earth that both holds it down and firms it up. Or keeps the sprout down and crushes it out. How does the son become himself?

Edsel Bryant Ford was an agent of his own free will and creativity. He was not a victim. He wasn't making the best of a bad hand. He would change the rules of the game.

\section{III}

Each person is more than the sum of their oppositions-how and what we are because of what we react against. But our reactions initially define us. We learn who we are as we come of age because of the ways in which we are not like our mother, father, sisters or brothers. Edsel Ford needs to be offset by his father to get him clearly into focus. His case was specially intense because this defining contrast pursued him publicly and privately his whole life long.

One of several strains that went into the make up of Edsel Ford was his creativity in areas which his father did not fully understand. Of single importance for the success of Ford Motor Company were Edsel Ford's contributions in automotive styling. Together with his design team headed by E. T. Gregorie (1908-2002), Edsel Ford revolutionized the company's automotive design. This was particularly visible in the Model A Ford, the Lincoln-Zephyr, the first Lincoln Continentals-the earliest models of which in the late 1930s Frank Lloyd Wright called "the most beautiful car in the world"-the Ford sedans 
of the late 1930s, and the early Ford Mercury. ${ }^{19}$ The company made enormous aesthetic progress motivated and spurred on by styling competition from General Motors Corporation and Chrysler, by the newfound power of the US female consumer and her preference for a good-looking car, by reacting against the backwardness of Henry Ford when it came to automotive aesthetics (as opposed to automotive engineering and mass production), and specially because of Edsel Ford's own sharp eye for what was both beautiful and useful.

Edsel Ford was primarily a visual communicator. His father was not. Henry Ford had poor visual communication skills (legend had it that Henry Ford could not even read a blue print); practically had image phobia. ${ }^{20}$ When journalist Ida Tarbell interviewed him around 1915 and commented on his inability to apprehend visual images, Henry Ford replied: "I do not understand them. The pictures I love are those I see through big windows when I look out into the trees, trees where there are birds." ${ }^{21}$ In the same vein, the famed art dealer Joseph Duveen, 1st Baron Duveen (1869-1939) visited Henry Ford in the 1920s with a custom made, three volume, illustrated book collection entitled "The Hundred Greatest Paintings in the World"-the originals of which Duveen and his business partners were hoping to sell to Henry Ford. Henry Ford quite sincerely didn't understand why these art dealers wanted him to buy the originals when they were offering him these illustrations. Henry Ford responded to the flabbergasted Joseph Duveen and his entourage, who had traveled all the way from New York City to present this offer, with: "But, gentlemen," said Henry Ford, "what would I want with the original pictures when the ones right here in these books are so beautiful?" 22

From his earliest childhood Edsel Ford was extremely adept at drawing and maintained his skill throughout his life. ${ }^{23} \mathrm{He}$ didn't develop it as a necessity because he had to run Ford's design department. It was his great pleasure and ability. He was an avid amateur photographer his whole life long. He had built and used a photographic developing room as an extension to his home office. He was an amateur painter and sculptor as an adult, and as late as the winter of 1932-1933 was taking lessons in painting and art history for his personal edification and delight. ${ }^{24} \mathrm{He}$ was very good in his own visual work, though he always insisted its status was only amateur. At the factory Edsel Ford commandeered an enormous photography and film division for purposes of private instruction and company record keeping. ${ }^{25}$

He insisted on his own amateur level as an artist. Partly, I believe, because he was fastidious about quality and precision. As the Great Depression deepened, he tried to tender a social statement for the company and common good by commissioning the commercial photographer and precisonist painter Charles Sheeler (1883-1965) to commemorate Detroit in general and the Ford Motor Company in particular. To accomplish this, Edsel Ford worked closely with Fred Lee Black (1891-1972) an extroverted jack-of-all-trades at Ford's. ${ }^{26}$ As head of the Ford Motor Company Advertising Department from 1927-1943, Black was one of Edsel Ford's closest and most-trusted colleagues.

Fred Black's and Edsel Ford's commissioned photographs are rather like monumental ice sculptures-the photographic studies of the Rouge Plant-produced by Charles Sheeler. Really quite beautiful photographs and, subsequently, paintings by Sheeler as well; but frigid. And private. Filled with an oppressive emptiness like an eternity of Sunday afternoons. Not public visions so much as solitary insights. Sheeler's Ford photos and paintings are obsessively perfect. Sheeler did not fill in the dots, he 
connected the atoms; with buildings and landscapes defined to the point of hyperrealism. ${ }^{27}$

In the end Sheeler's meticulous work did not translate to the general public. Sheeler and his kind, notably Charles Demuth, Louis Lozowick, Georgia O'Keefe (in her 20s, New York City paintings), George Ault, Niles Spencer, Elsie Driggs, Stefan Hirsch, and others were "Immaculates" who reduced the visible world to dynamic geometric shapes; who consciously celebrated the "America of their time by concentrating on what"-they thought-"best typified its power and self-sufficiency: its industrialism [...] [of] factories, steel mills, elevators, and smokestacks." ${ }^{28}$ Things. Machines. The satisfying logic of productive structures.

When the Precisonists, and Charles Sheeler did not seize the heart and mind of the public's attention, it became Edsel Ford's primary intention to reach out as his company's PR and arts' manager to find someone who could materialize a vision which moved the general public. And make a difference. This is where Diego Rivera became so important and opportune in the life and times of Edsel Ford.

31 Edsel Ford personally had a specially keen eye for managing composition, the arrangement of shapes. His favorite color was grey, a shade known as "eagle grey"which one can see in his personal Lincoln Continental at the Edsel and Eleanor Ford House to this day at Grosse Pointe Shores, Michigan. His eye for quality arrangement was a great asset in automobile design. He specially managed Ford's upmarket products, mass media relations, visual appeal and advertising, while his father managed the engineering-specially for the mass market automobiles.

Edsel Ford practiced styling in the largest sense of this term. As the biographer William Richards noted in 1948 soon after Edsel Ford's death, and following extensive research both in the early, unexpurgated Ford Archives and in personal interviews with surviving witnesses among Ford Motor Company executives, "it was only after Edsel's appearance in a major role that radio programs, progressive sales campaigns and the use of practically every form of advertising media appeared in the Ford picture." ${ }^{29}$

The actual purchase of Lincoln automobile from Henry Leland in the 1920s was a very acrimonious affair. But the result was Edsel Ford's successful emphasis on quality and design with the revamped Lincoln automobile division of Ford Motor Company which he directed. When the Lincoln purchase deal was being negotiated, Edsel Ford disclosed with typical brevity and discretion to a friend with whom he was playing golf one day: "Father made the most popular car in the world; I would like to make the best car in the world." 30

Edsel Ford's visual attention came out in two other striking, personal ways.

In the mid 1930s New York City's leading tailors publicized one of the first American "Best-Dressed" lists. Number one on the list was Edsel Ford, number ten was Fred Astaire-the good-humored, Omaha, Nebraska hoofer who "has done more this year to encourage the wearing of tailcoats than anybody else". While Edsel Ford was singled out as "the "Beau Brummel of Wall Street" and "the perfectly dressed business executive." ${ }^{31}$ Why?

Was "Beau Brummel" a misnomer? Because of Hollywood's two movies about Brummel and popular culture's subsequent use of the man one associates Brummel with flamboyant over-dressing and vapid dandyism. But Brummel's dictum was that "If people turn to look at you in the street, you are not well dressed." ${ }^{32}$ It demanded 
extraordinary exactitude to be elected America's Best Dressed man. Money helped. But money itself didn't make it happen.

Sometimes wealthy men who did make America's Best Dressed list in Edsel Ford's generation, notably Alfred P. Sloan of General Motors-with his signature high, white, starched collars, who looked stiff as a plank of lumber, and always wore an anorexic Boris Karloff face-was well-dressed, but not elegant. ${ }^{33}$ Edsel Ford from his childhood was naturally elegant. He never dressed as a distinguished elder gentleman. His style did not age. It was as classical as his best automotive designs, as neat as a Doric column. Elegance lies in understatement and cool.

Then there's the Edsel and Eleanor Ford House (completed in 1929) as a place, a heritage, and a personal expression. Grounds and building are on both the Michigan State Register of Historic places (since 1977) and the US National Heritage of Historic Places (1979). The relatively intimate and simple stone mansion itself was built by Detroit architect Albert Kahn (1869-1942) in close collaboration with Eleanor and Edsel Ford's wishes and personal research.

It may sound odd to speak of a sixty-room house with three stories and a basement, on an area of land originally occupying over one hundred and twenty-seven acres (including twenty-seven acres across Lake Shore Road) as "simple". But a factor which enhances its simplicity is the difference between the public, grandiose area downstairs in the house designed to receive guests and the private family quarters upstairs. The family's private upstairs rooms are all about the size one would expect a normal, midcentury, American middle class family to have. The rooms are cozy but not huge. They are the sort of rooms one could almost imagine a suburban middle class Leave It to Beaver or Ozzie and Harriet family to have. Since the Edsel and Eleanor Ford residence has become a house museum visitors, about 50,000 a year, are regularly surprised by the modesty of the private family space. ${ }^{34}$

The home's landscaping is however quite dramatic and remains one of the best surviving samples of Jens Jensen's school-of-the soil, prairie-style, native plants' and materials' work in the United States. When Eleanor Ford passed away she donated the house to the State of Michigan as a public center and museum. She wanted to "preserve the residence for some form of public use," so that it could remain as one of the "witnesses to the past, as part of the history of the area, and as an enrichment in the lives of future generations"; hence the residence was left "along with suitable furnishings [...] and the property to be used for the benefit of the public." It exists and thrives to this day as one of the few remaining "auto baron" estates in greater Detroit and is a deliciously haunting celebration of place. ${ }^{35}$

41 For a man who made cars, with their insatiable appetite for busy space, a place was created far from noisy, hazardous traffic. Businessman as artist takes on another sense here: the art of the home. As Winston Chrchill said: "We shape our buildings; thereafter they shape us. ${ }^{36}$ Here is home as a cultural instrument. Stone and wood are the dominating materials. The iron and steel mechanical modern is absent. It's a positively creative escape.

The elbow of land on which the Edsel and Eleanor Ford House rests on Lake Saint Clair was used for many years by the large bands of Chippewa and Huron tribes who would leave their families there when the men went down to the colonial fort at Detroit. ${ }^{37}$ The Edsel and Eleanor Ford House is best seen in the early morning, among the lake fogs, brushed away by the rising sun. Built to resemble a cluster of Cotswald cottages, it is an 
emotional response to nature-"a sort of lead into nature through sentiment and memory." ${ }^{38}$ It is a romantic building. A structure of old stone, thick walls, blankets of English grape ivy, lush lawns and great elms which stand like sentinels both delicate and strong. But an invention and revelation of local reality. Since this is Michigan and not the Cotswalds.

The Eleanor and Edsel Ford home was built by architect Albert Kahn at a discreet distance from Clara and Henry Ford's lugubrious, cramped and architecturally incoherent Fair Lane in Dearborn, Michigan, at the other side of town. (Clara's and Henry Ford's Fair Lane has since been made far more coherent since it became a national historical landmark). The Edsel and Eleanor Ford House is built with its back to the land and its face to Lake St. Clair. Face to face with "earth's eye; looking into which the beholder measures the depth of his own nature." ${ }^{39}$ Its sense of place is a green garden floating on water, guided by the tall masts of trees, bulwarked by stone.

Philanthropy was another expression of Edsel Ford's creativity. The immediate cause was practical. Under the presidential administration of Franklin Delano Roosevelt in the Great Depression era of the 1930s a whole new range and depth of corporate taxation was created by the US federal government. Firmly in power, Roosevelt pushed for a wide range of increased corporate, estate, and inheritance taxes along with "stepped-up income taxes on 'very great individual incomes'."

Eleanor Ford and Edsel Ford likely worked closely together on this matter of the Foundation because of their personal preferences and the customs of their native culture. Since colonial times-and for a variety of selfish, unselfish, and in-between reasons in America-"giving money away in order to relieve distress or to advance some cause considered worthy is something that individuals [...] have been willing to do on a larger scale than in any other nation. One may say that Americans, living in relative plenty, have had more to give than others." ${ }^{41}$

By the early twentieth century a tradition of hard-nosed, humanitarian aid and institutions was well established in the United States, notably in the Midwest by the Progressive movement and its outstanding local figures such as Henry Demarest Lloyd (1847-1903), Jane Addams (1860-1935), and Detroit's own J. L. Hudson (1846-1912). We know for a fact that Jane Addams was Eleanor Clay Ford's own personal hero who she tried to emulate in different ways. Edsel Ford's wife grew up in her uncle J. L. Hudson's home after her own father died in 1908. Hudson was a major Detroit retailer who was very actively engaged in local social welfare programs. There's every reason to believe that Eleanor Ford took her heritage of building and repairing the ladder of success for her own family and the community very seriously. In turn the older couple of Henry and Clara Ford promoted public education for the needy young by aiding individual schools. But their son's resourcefulness in the area of philanthropy was unprecedented in either family. ${ }^{42}$

Without Edsel Ford's leadership the Ford Foundation (1936- ) would not have existed. In contrast to his father's neglect, he created it. ${ }^{43}$ Since its inception the Ford Foundation graduated from local philanthropic activities in Michigan to consistently being one of the three biggest philanthropic trusts in the world; for decades it was the world's largest. This achievement was due largely to Edsel Ford's structured intention worked out with his team of lawyers and the nature of his personal vision kept in action by his wife Eleanor Clay Ford and Edsel Ford's eldest son Henry Ford II. 
This is not to say that the philanthropy of the wealthy is all roses and sunshine. It makes good sense as public relations. But the very rich are not obliged to take this route when it comes to investing and developing their wealth.

A new chapter was written in American philanthropy beginning with the legacies of the great Carnegie, Rockefeller, Morgan, Peabody and Higginson fortunes made in the late nineteenth century. Carnegie preached "the man who dies rich dies disgraced", but that didn't stop William Rockefeller-John D. Rockefeller's partner and brother-from giving almost nothing to charity. In 1930 there were only about one hundred and fifty US charitable foundations, but by the year 2000 the number stood at more than fortytwo thousand.

Should the wealthy choose to give has been a matter of choice and character. Basic research shows that the vast amount of charitable donations in the US twentieth century-about 85\%-came from middle-class Americans and not from the high-profile high rollers. The matter of public relations is over rated. More to the point is the conversion of private wealth to public purpose to further individually chosen aims. Or as the self-made American millionaire Percy Ross (1916-2001) supposedly once said: "He who gives while he lives also knows where it goes."

One sees in the Ford Foundation a direct extension of Edsel Ford's pioneering work in Ford Motor Company's Sociological Department headed by John R. Lee and the Reverend Samuel Marquis (1866-1948). This Ford Motor Company division was created in 1913 and phased out of existence in the early 1920s. The Ford Foundation subsequently strongly supported social science research and education. Edsel Ford publicly stated he wished he had experienced more education (his most advanced degree was his high school diploma, Detroit University School, 1912). The Foundation paid special attention to scientific research in medical areas. Edsel Ford personally suffered from acute ulcers in the last decades of his life and eventually died of a stomach cancer. Last but not least, as the Foundation developed it was used to correct social ills engendered by Henry Ford in his own lifetime-notably his reckless, crowdpleasing anti-Semitism.

With regard to Edsel Ford, his businessman's creative art also resides in his imaginative moral use of wealth to help build a legacy and to correct contemporary wrongs.

Eleanor and Edsel Ford had tried to set right Henry Ford's anti-semitic wrongs while Edsel Ford lived. But, unfortunately, could not. There were a lot of good things about Edsel Ford's father: the Model T, soy bean research and development, his health policies regarding vegetables and his anti-smoking campaigns, his attempts to deregionalize factories, Ford Motor Company's very progressive labor policies for handicapped workers, and prior to World War Two his positive assistance for Detroit's African-American community (for which he was highly praised when he died in 1947), and not least of all his Quixotic attempt to stop World War One with his ill-fated peace odyssey on the ship the Oscar II to Norway in December 1915.45

But the story of Henry Ford and the Jews is a shameful stain on the man and his reputation.

This story has been told before and will be told again. From approximately early to late-1920s Henry Ford owned a weekly newspaper called The Dearborn Independent. It was a kind of 1920s Grit. ${ }^{46}$ Henry Ford wanted it to be an inexpensive, wholesome family newspaper with general feature articles that were meant to be "entirely nonfiction, 
educational, and presumably factual. ${ }^{{ }^{47}}$ To emphasize his weekly's family nature, its main editorial staff were initially listed as: "Henry Ford, President. C. J. Ford, VicePresident. E. B. Ford, Secretary-Treasurer. E. G. Pipp, Editor." ${ }^{48}$ That is, a father, mother (Clara Jane Ford), son (Edsel Bryant Ford) production.

The Dearborn Independent was not the first publication launched by Henry Ford's company, but it became his most notorious. Edsel Ford and his mother soon resigned from The Dearborn independent in silent protest against his father's policy of antiSemitism in the paper's articles. But other people resigned first-as journalist Edwin G. Pipp did in mid-April 1920.99

From its first issue in January 1919, Henry Ford obliged Ford Motor Company dealers across North America to distribute and sell his weekly newspaper. The rule was: no newspaper, no cars. He wanted a million copies of this paper sold a week. But The Dearborn Independent didn't sell and dealers wound up buying and junking copies. In its first year alone The Dearborn Independent is estimated to have lost $\$ 284,000$ (equal to about $\$ 3,491,621.43$ in 2009 dollars). In its inaugural year it had the low national circulation of about 72,000 . It finally went out of business in 1927 , and probably never turned a profit..$^{50}$

In May of 1920 The Dearborn Independent began an off-and-on series: "The International Jew: The World's Problem." ${ }^{51}$ Edwin Pipp saw this coming and resigned. This series began with the three sentences:

The Jew is again being singled out for critical attention throughout the world. His emergence in the financial, political and social sphere has been so complete and spectacular since the war that his place, power and purpose in the world are being given a new scrutiny, much of it unfriendly. Persecution is not a new experience to the Jew, but intensive scrutiny of his nature and super-nationality is.

And so on.

The accumulative years of the Dearborn Independent's anti-Semitic texts are very difficult to read. It is rant; anti-foreigner harangues which vehemently scolded Jews and non-Jews. About the Jewish people in particular, the paper noisily declaimed in a fever pitch of soapbox anger:

There is no Christian church that the Jews have not repeatedly attacked ${ }^{52}$; Jews did not create the popular song; they debased it. ${ }^{53}$; Bolshevism is working in the United States through [...] Jewish agitators. ${ }^{54}$; Zionism [...] always embroils the nations which become Jewish tools ${ }^{55}$; This propaganda of pogroms-'thousands upon thousands of Jews killed'-amounts to nothing except as it illustrates the gullibility of the press. ${ }^{56}$; Jews [...] constitute a problem for the Jews themselves [...] [and] It is time for some one to call attention to the necessity of cleaning up on that problem. $57 "$

"The International Jew" was not the Wansee Conference and it fell short of calling for a "final solution". But, as can be read in these sample lines, it was a sick text for sick times-nativist, 1920s, isolationist America; a time and temper castigated in the interwar, Warner Brothers, social-problem film Black Legion (1937, dir. Archie Mayo).

61 The "International Jew" series was immediately published in book form and never copyrighted. It spread like a weed. From the 1920s onward The International Jew was translated into far too many foreign languages. Plus translations of fraudulent antiSemitic materials were included in The Dearborn Independent. Most notorious of these was the false Protocols of the Elders of Zion. ${ }^{58}$ 

president. He approved the content. And its lead title was The Ford International Weekly. We know from archival records that Edsel Ford monitored the affair closely. It greatly offended Amlerica's Jewish community. Yet in Detroit itself, the "International Jew" series had very little or no effect on community anti-semitism. Edsel Ford also 
discovered that this Dearborn Independent series did not harm sales, even in Jewish communities. Finally, however, he decided that something had to be done.

Zedek Synagogue, founded by Rabbi A. M. Hershman in 1909. But Mr. Friedberg belonged to a minority group within his own community. Rabbi Leo M. Franklin of Beth El Temple was the major public figure at that time in Detroit's Jewish community. A true Solomon of a man in his own right. Franklin was friendly with Henry Ford until the Dearborn Independent began its anti-semitic propagandizing. Although he broke with Henry Ford, Rabbi Franklin did, on occasion, meet him again-and argued that Mr. Ford was a repentant sinner. And should be forgiven. ${ }^{70}$

74 Following the genocide of World War Two, it became very hard for anyone concerned to forgive any public figure of the prewar period who had incited anti-semitism. Why forgive? Yet Rabbi Franklin's last, unpublished work, Some Untold Tales of Detroit and Detroiters (1947) made a wise argument for forgiving his old, ex-friend Mr. Henry Ford. Curiously, this work by Rabbi Franklin remains unpublished to this day. ${ }^{71}$

In any case, back in the Twenties, as Detroit's leader of the Reform movement, Franklin was a committed non-Zionist. For Rabbi Franklin there was " 'only one country, America, and but one flag, the Stars and Stripes.' He believed that a Jew living in the 
United States should be a loyal citizen of his country and should hold no political interests anywhere else-including Zion."72

But since the time of World War One, and specifically the Balfour Declaration by the British Government of November 2, 1917-which viewed "with favour the establishment in Palestine of a National home for the Jewish People"-a debate raged in the American Jewish community about Zionism. ${ }^{73}$ Many factors heightened the Stateside Zionism controversy: such as the American immigration restriction law of the period; organizations of non-Jews in the USA which supported Palestine rebuilding; Christian ministers appeal for Palestine relief; strong appeals made in the US among urban, East Coast Democrats to aid United Jewish campaigns. ${ }^{74}$ So when Edsel Ford made his move to loan $\$ 1,000,000$ in 1926 to the Zionist investment corporation in Detroit it did not happen in a vacuum. Businessman that he was, he was also not moving alone.

Unfortunately, Edsel Ford's offer was rejected.

As the firsthand report noted, following Edsel Ford's offer to Morris Friedberg from Detroit's Guardian Trust Bank:

'the negotiations did not culminate due to criticism expressed in certain Zionist quarters of the enlistment of Ford's cooperation. This criticism was based on the fact that an avowed enemy of the Jews, as Henry Ford was considered, could not be permitted to cooperate with Zionists in the rebuilding of Palestine. ${ }^{75}$

As so often happened in his life, what Edsel Ford did was mistaken for what his father did. The facts were poorly examined. European newspapers and Jewish community leaders, both in Germany and Eastern European countries jumped to the conclusion that this $\$ 1,000,000$ loan offer was a false gesture of contrition from Henry Ford.

Yet the Jewish community locally and nationally were eventually cool headed and open minded enough to recognize that Eleanor and Edsel Ford had very different beliefs from Henry Ford. As Albert Lee wrote in Henry Ford and the Jews (1980): Edsel "had never expressed the Anti-Semitic notions of his father, and many knew that Edsel had often disagreed with the old man over the issue." ${ }^{76}$ Still, Edsel Ford's good will wasn't enough to assuage anger against the biased elder.

We know Edsel Ford did not give up. We know that Eleanor and Edsel Ford continually and consistently made efforts to bridge the gap and increase sympathetic understanding between the Jewish and non-Jewish communities. I believe that Edsel Ford's actions show that his credo, as expressed by Dr. Solomon B. Freehof in a public lecture on "Zionism and the American Jew" in Chicago in 1927, was that "we must honor and value each other's differences. We must respect each other's varying philosophies." 77

81 What happened a few years later in Detroit with Edsel Ford and Diego Rivera would be another example of converting private wealth to public purpose to further individually chosen aims. And it would be one project that would succeed.

A last point about character and management before we turn to Detroit itself, and to Diego Rivera and a concise look at the Detroit Industry Murals. 
In literary analysis one speaks of a character who is a "foil". It's a fencing term. The foil is strictly the handle of the sword. But used in literature a foil is a metaphorical extension of the protective leaf, shell or coquille that protects the fencer's hand and wrist from the opponent's striking blade and probing point. The foil greatly protects and enhances the fencer's strength, allows for strategic deception and quick response. In story sense a foil both reflects attention from the main character and protects him. The foil emphasizes, enhances, and complements traits which the main character lacks, has but latently, or needs to develop. Equally the foil can be attacked in place of the main character. ${ }^{78}$

Henry Ford had the two foils of his wife and son. Both radiated common sense, stability, and constant encouragement in corrective complement to Henry Ford's swagger, impetuosity, and bullheadedness. Without his wife and his son he would have been a river without banks.

Clara Bryant Ford was a farm kid like her husband and could always recall the values of that world to him. Clara cherished rural simplicity, knew her own mind, maintained an elder sister's role of family organizer and peacemaker. She embodied home as common heritage, since she and her husband both came from successful pioneer families out in Dearborn, Michigan. Even more, Clara Jane Bryant Ford "was married for fifty-nine years to a man who called her 'The Believer,' and on many occasions he tested her belief in him sorely."79

Edsel Ford had a harder role to play as foil. He had to offset his father's management weaknesses-and they were legion. He had to reverse Henry Ford's errors by his own actions and not just offer pale reactions. He had to be and become himself independent of his father. Working in a shadow land did not stunt his growth. On the contrary, it made Edsel Ford mature and allowed Henry Ford to remain more like a child-one who cared more for power than for money. ${ }^{80}$ The son-father partnership yoked the methodical and the impulsive; Edsel Ford strained and Henry Ford gained.

Plus Henry Ford's success did not follow a formula or a pattern which anyone could repeat. His heroic charisma was one of a kind and his Model T success was trumpeted as a one man show. Edsel Ford's inextricable role in this scheme of things had to be powerfully discreet; eagle grey versus his father's flash. If he spoke little, he heard and thought the more.

Finally, at a time when companies were still very patriarchal, this father-son relation made its own kind of sense to workers and executives at Fords. For insight on its meaning it is worth quoting Harold Hicks, a Ford Motor Company executive of their time. Harold Hicks noted of the two men that up close and personal as colleague and boss Henry Ford:

[...] was bitterly sarcastic [...] Henry Ford was a peculiar man. He would tell you he was going to do a certain thing, and he'd turn right around and deliberately do the opposite. That used to upset you. You never could count on anything. You didn't know what he would do from one day's end to the other [...] it was upsetting [...]

[...] I often thought no one would have stayed here as long as they did had it not been for Edsel Ford.

You always figured that there was one person who was a perfect gentleman, and that some day he was going to run the place, and it would be a fine place to work when he was running it. You stuck around because of him. Whereas the big shots in the organization, like Sorensen, Martin, and Bricker, were all controlled by Henry Ford himself. They did everything he told them to do. Yet at the same time, they did 
very little as far as the actual details were concerned.

It was that group of loyal people, people who were loyal to Edsel, I think, that had an awful lot to do with the success of the Ford Motor Company. Very little was ever said about the excellent moral influence Edsel had on the people that worked here in the Ford Motor Company." 81

The father's authoritative paternalism kept others on their toes, alert, off-balance, hard working yet subdued. While Edsel Ford's attitude toward workers and colleagues was based on mutual respect (an attitude sanctified by Rivera's vision of human relations in the Detroit Industry cycle).

\section{IV}

Detroit itself needs some words of explanation to understand how business can be an art.

91 A city is a man-made risk. It is a creation which thrives by expectation. A great city is a magnet. The greater the city, the bigger its draw. Detroit was a frontier town, a border city on the Great Lakes, drawing in people from around the world. By the early 1600 s Europeans were settling America along its fringes in San Diego (1602, California), Jamestown (1607, Virginia), Santa Fe (1610, New Mexico), and even the Detroit area had a few Europeans by the early 1600s. There was economic, geographic and cultural logic to holding this area and using it as a trading base. It commands a narrow river strait into which Lake Ontario and Lake Erie feed in from the East, Lakes Huron, Michigan, and Superior from the west.

The first, formal, European settlement of Fort Saint Joseph was established there by the French pioneer ranger Daniel Greysolon Dulhut in 1686, abandoned by 1688, but then re-founded with a vengeance in 1701 as a self-sustaining French trading outpost-FortPontchartrain du Détroit-by the colorful Antoine de Lamothe, Sieur de Cadillac. Cadillac had alternately been a French soldier, navigator, privateer, enemy of the Jesuits and prisoner in the Bastille, a military governor who made Detroit prosper as an important market in the fur trade for beaver pelts with the native Algonquians. Over time the place would be fought over and owned by France, Britain, and the United States. It is just across the river from Canada, where by the mid $19^{\text {th }}$ century the Canadian Great Western Railway had its terminus in the town of Windsor.

The Eastern Standard Time Zone stretches out seven hundred miles and holds Detroit in its grasp, as if it's part of that original East Coast flank that drew in the original settlers to the promise of a new world. Yet Detroit is thoroughly Michigan and Midwest. Gulls off Lake Erie and Lake Huron pepper the place with insolent squawks. Drive down the coastline Jefferson Avenue and Lakeshore Drive and one sees out on to the Detroit River and across Lake Saint Clair, sees strings of long, low lake freighters heading north to Michigan's Straits of Mackinac and Canada's Sault Sainte Marie.

Detroit became the Jerusalem of US factory towns. Individual energy, population inflow, urban and industrial growth boomed up together here. But lurking near Jerusalem was always the gates of Hell. "No sooner is a Temple built to God," as the British proverb goes, "but the Devill builds a Chappell hard by." Here was equally the risk that one could be "turned by force into a machine oneself"-as the author LouisFerdinand Celine wrote about his own experience as a Ford Motor Company assemblyline worker in the 1920s. Where it seemed that "one only lived in a sort of suspense 
between stupefaction and frenzy. Nothing mattered except the continuous feeding of the several thousand machines." ${ }^{82}$ It was a place of tension, speculation, self-confidence and the friction of brittle needs.

Look deeper into the sense of place.

Ever since it came of age as its modern self in the late nineteenth century the City of the Straits has been an edgy, explosive town. For a series of reasons. First came its boom town growth; tantamount to building a city on a fuse. Back at the turn of the century in 1900 it was America's $13^{\text {th }}$ largest city with a population of 285,704 . By 1920 Detroit had a population of over two million inhabitants and was America's $4^{\text {th }}$ largest city. It maintained this status until 1945, in spite of severe economic and social suffering during the Great Depression.

Detroit received a temporary reprieve from the Depression's depleting pressures when it proved its ability to organize its resources and won the title of the nation's "Arsenal of Democracy" during World War Two. Jeeps, airplanes, tanks, ambulances and all sorts of equipment, apparatus and supplies needed for America's successful military effort were manufactured here and elsewhere in Michigan. The Arsenal of Democracy allowed the calm witnessed in the children's upper room in Norman Rockwell's painting Freedom From Fear (1943). America's industrial production was the sea wall holding back the storm.

War production was shield and armor. Kilns were fired. Swords were forged. In the end Michigan produced more war munitions than any other American state during World War Two. The most spectacular factory was Ford Motor Company's Willow Run Bomber plant which evolved from the joked-at "Will It Run" plant beginning in May 1942 to eventually mass producing 8,685 B-24 Liberator bombers at a rate of one every eightyfour minutes..$^{83}$

9 For many Americans in the twenty-first century it might be hard to recover the sense of enthusiasm felt by most Americans in the "Fighting Forties" for the USA's spectacular wartime industrial productivity. There was no shame about US war production back then. President Eisenhower's morally ambiguous accusation about the United States "military-industrial complex" and America's international role as the world's policeman hadn't become part of the nation's worried psyche.

To understand Detroit one has to respect people who worked at all levels in industrial manufacturing-specially the line workers-and adapted to what was needed for the hard policies of wartime national security and the maintenance of business that would prove to be commonwealth foundation for national prosperity after the war. (In this vein Americans of a certain generation will remember a radio then TV sitcom called The Life of Riley from the 1940s and 1950s, starring William Bendix, which both praised and poked fun at this contemporary, prosperous world of a blue-collar lug, his work, friends, and family. ${ }^{84}$ ) Factory work was a mixed blessing. And Detroit was the greatest blue-collar town America had ever seen, a saving grace for America-until its fall came.

Second, from 1900-1950 Detroit was America's second largest immigrant city. Extensive international immigration was a state-wide phenomenon and by 1940 more than half of all Michigan residents were foreign born or had foreign-born parents-many funnelling 
into Detroit which boiled with immigrant hunger and hard work. ${ }^{85}$ This put Michigan and Detroit way above what is now considered to be current excessive norms for foreign-born people in a Western country, such as Greece and Ireland which now calibrate troubles and woes due to immigrants because the number of people working outside their homeland in Greece and Ireland has risen well above $10 \% .{ }^{86}$

Third, one of the issues native but not unique to Detroit was the large domestic migrant population of poor rural whites and blacks from the US South who poured into the city and were concentrated labor in the car factories and competed for limited housing space in town. This domestic migrant population carried the explosive old baggage of its divisive racial prejudices. Relocated in a much freer and more mobile industrial environment of shifting places the friction between Southern blacks and whites simmered like corrosive chemicals under hay piles in the hot sun ripening toward spontaneous combustion. Two results were the Detroit race riot of June 1943 (a month after Edsel Ford's death) and Detroit's massive $12^{\text {th }}$ street riot of July 1967.

Fourth, the nature of its economic growth was Detroit's most singular and incendiary $20^{\text {th }}$ century characteristic. This economic time bomb was ultimately more destructive than the city's race problems. One can get deeper into the matter of its problematic economic growth by asking: Why does a city exist? How does it grow?

A first explanation is the notion of the primal seed. Which means the essence of a human group's dwelling was there even before it fully existed because the city lay dormant in the place. Poet Robert Frost once used this notion about the American nation itself in his line "The land was ours before we were the land's" in his 1961 presidential inauguration poem "The Gift Outright". With this notion, the great city is pre-formed, a homonucleus that begins in embryo.

105 A second explanation-as urban historian Jane Jacobs (1916-2006) pointed out, and singled out Detroit as her prime example-is the idea of urban epigenesis. In this case "a city grows by a process of gradual diversification and differentiation of its economy, starting from little or nothing more than its initial export work and the supplier to that work. ${ }^{87}$ A city grows not from a homonucleus seed, but as a new creation through the action of what it brings to the environment. A city is not a matter of preformation but accumulation.

106 By witness of the Detroit Industry Murals, I think both Edsel Ford and Diego Rivera realized that cities are made, not born. And likewise realized special local resources had to be available. Cities are built out of local talent and resources, along with materials they attract and invent. It takes both primal seed and epigenesis. What results is the city unique and what the city makes of itself.

107 That cities are made not born, is attested to by historical fact. The rise of land along the waterway between lakes Huron and Erie that the Wyandot tribe of the Huron indians once called "Yondotin" was not destined to be Motor City and the Arsenal of Democracy. ${ }^{88}$ Detroit was built up through buying, making, selling things from Michigan and the fecundity of the Great Lakes region which cradles the Wolverine State. But specially by the cooperation and labor of its Michiganders. Who would work, up the ante, go to work again, repeat their boom, bust, and boom cycles all over again.

Diego Rivera's Detroit Industry Murals are witness to understanding this phenomenon between the two men. The actual experience attests to what's valued. This fresco of twenty seven, organically connected paintings is witness and amanuensis to their 
constant discussions and consultations-which otherwise have not a single, photographic or written record. ${ }^{89}$ industries. cars. the car.

Detroit's growth curve was rapid and thorough. Its first big product after it was founded in the early 1700 s was beaver pelts for European hat makers. But by the early 1800s local beaver levels were seriously low. Meanwhile lots of other natural resources were under development, specially those based upon lumber, iron ore, copper and other minerals that were used to make stoves, railroad cars, ships and natural extracts used to make medicines and chemicals.

Take copper products, for example, which were Detroit's largest export in the late $19^{\text {th }}$ century. Then the local copper supplies ran out. The copper manufacturing industry moved elsewhere. Detroit had to import copper. Its export industry generated an import industry. While new forms of manufacturing production were found and the city's growth fanned out, expanded, and continued. Growth accrued based on other products that were developed after the copper industry left.

When Detroit's car industry started around 1900, the necessary foundation of diverse industries were locally in place to make this new industrial expansion possible. In retrospect one can see that this condition was more fortunate than in any other American city of the time. The raw materials were there in Michigan's mineral-rich land and heavily-wooded Upper Peninsula. A tradition of ship building meant engine building craftsmanship was a local strength. Investment wealth was concentrated in Detroit's banks and barons from the previous, successful generations of local Michigan profits in lumber, shipping, and heavy manufacturing a variety of products from stoves to railroad Pullman cars. Mechanics, tool and die makers, engineers, electricians and iron smiths thrived locally from transportation's bicycle, ship building, and railroad

2 Then came the lock in the fateful marriage of industry and product. From 1900 onward most businesses in Detroit were harnessed to the car industry; the concentration of indigenous forces into a totally new product. By 1940 three-fifths of the world's automobiles were made in Detroit..$^{90}$ Finally by local, national measure Detroit's automobile industry directly catered to the world's largest car market, the United States itself. And there was then no foreign competition for low-cost, mass-produced

Almost all the diversification and differentiation of the economy that had developed since Antoine Laumet de La Mothe Sieur de Cadillac founded the settlement of FortPontchartrain du Détroit in 1701 was gradually and finally channelled into this alldevouring growth of the American automobile industry. This was a bootstrap culture of the first degree that developed by way of its own initiative, hard work, proud exploitation of local resources and self-reliance. Which finally bet it all on one machine,

$$
* * *
$$

Detroit in its heyday was riding on a San Andreas fault. The city cornered the automobile at cost. The real magnitude eight earthquake would not hit Detroit until 
after the 1973 oil crisis when mainstream US car consumers began to turn away from Motor City vehicles in order to buy higher quality, more economic foreign brands. ${ }^{91}$

Detroit was at the heart of America. To turn away from her meant rejecting a power in the lifeblood of the American $20^{\text {th }}$ century experience.

There were rational, pocketbook reasons for this rejection. But there were reasons of the heart as well. Americans were deeply disappointed in their own nation. Track America in the 1960s and 70s and you follow a wounded animal's trail. By the postwar 1970s the nation was a shoddy, bloody shambles. Hit and wounded by the failures of the Vietnam War, Watergate, political assassinations, urban decay, cynical leadership, race wars, white flight, and a president you'd rather impeach than support - but who got away with it all and waved a victory "V" from the steps of the presidential helicopter. Sick at heart, Detroit was rejected.

117 The Great Depression of 1929-1941 anticipated the crisis that would happen locally a few decades down the road when people stopped buying the city's main export product, its cars, and the intensely eclectic local population of Detroit could no longer get along. But Americans, and Detroit, in the 1930s and 40s also recoiled from that descent.

118 Writing soon after the Detroit Race Riot of June 1943 in which an estimated 34 people were killed and many hundreds injured, the African-American Louis Martin, editor of The Michigan Chronicle, recognized that Detroit could brew up "a social disorder which has often come very close to anarchy." But Mr. Martin took hopeful measure of his city as "a thrilling illustration of industrial genius" that was rapidly packed in a few decades "with the peasants and the backwoodsmen of many races and nationalities", packed with people who came "to Detroit by the hundreds of thousands [...] to work with their hands and to sweat their way to prosperity by feeding vast furnaces and building giant machines with which to build more machines ad infinitum." ${ }^{22}$ Even when friction fired up between working-class groups based on old antagonisms, the city found within itself an inner resource to cooperate, progress, and prosper which it later forfeited.

The city's resistant, resilient spirit was a vital factor in its common success over many years. Even though labor and racial tensions mounted, Detroit pulled itself out of the Depression. Even when difficulties multiplied between the management of different industries, within individual corporations, and among labor groups themselves with very different world views, leaders and solutions. At its heart there was always a no nonsense, park it or drive it way about Detroit.

Clint Eastwood's 2009 movie Gran Torino was a warm, hard nosed, bitter sweet, tragic eulogy to the spirit of place embodied by Detroit. Go back to the late 1800s and you can find much the same characteristic wry grit. On December 30th, 1893, a month after Edsel Ford was born, the Detroit Free Press newspaper ran a short give-and-take joke in its holiday humor column "Side Remarks". A scruffy tramp came to a decent, middleclass citizen's door. He complained: Bum: “'The world owes me a living!' " And the response: “Citizen: 'Well, I'm not the world. Get out.' " ${ }^{93}$ 


\section{V} teacher Elie Faure. and crashing waves.

In this context of Edsel Ford, Detroit, the Great Depression, comes our last example of Edsel Ford's many facets of creativity-his collaboration with Diego Rivera.

Diego Rivera (1886-1957) was a Mexican citizen, the child of ambitious, middle-class parents. He was very proud of his diverse racial and religious lineage: Aztec, Russian, Spanish, Portuguese, Mexican, Jewish, Catholic, Masonic and atheistic ancestors. ${ }^{94}$ Exceptionally gifted in drawing as a child, his abilities were nurtured in Mexico by his parents, his education, state scholarships and individual support. His personal sponsorship in Mexico ranged from the politician and Governor of Veracruz Teodoro Dehesa (1848-1936) to the philosopher-politician José Vasconcelos (1882-1959) and among Americans from the US Senator and diplomat Dwight Morrow (1873-1931, the father of Anne Morrow, the wife of Charles Lindbergh) to the gifted movie actress Paulette Goddard (1911-1990). As a young man, Rivera matured slowly but surely in Mexico and in Europe.

He learned and practised his mural art in Italy, but specially honed his creative abilities from the years he spent among the generation of cosmopolitan artists who lived and worked in Paris around the time of World War One. This was the generation which included figures such as Guillaume Apollinaire, Gertrude Stein, Max Jacob, Erik Satie, Maurice de Vlaminck, Marc Chagall and Pablo Picasso (who gave Rivera his nickname "the genial cannibal" ${ }^{5}$ ), along with the soldier, surgeon, art critic and Rivera's greatest

Rivera was politically exuberant in that sense of national mission and combative opposition to a privileged elite which characterized his generation of engaged Mexican artists and intellectuals. But he arrived at this position very gradually; in the full sense not until he returned to Mexico after his many years of self-imposed exile in Europe. He was populist, Communist of a sort, and anti-establishment at times when it suited his personal likes or dislikes. Then at other times he was elitist, traditionalist, aristocratic in nature. As an artist Rivera had an extraordinary degree of negative capability, which helps explain his receptivity and empathy for such a wide variety of human types and values (for which Rivera was often criticized by strict, leftist ideologues). ${ }^{96}$

Rivera was a bohemian anarchist and a professional artist, "a product of the discontented middle class" as he said of himself. ${ }^{97}$ He passionately believed in and practised the intelligence of the senses; was a man of sight, touch, and speaking, not reading or writing. With Rivera passion was the paradox of reason. Which is to say, in his full maturity he was ever an impulsive, alternately charming or abrasive, charismatic and deeply egoistic man. He lived and worked in America during the depth of the Great Depression and his art done there at that time is both rooted in that troubled era and transcends it. Like an ocean weed, he thrived amid chaotic currents

The Detroit Industry Murals created by Diego Rivera and his team of artisans in 1932-1933 at the behest of Edsel Ford offered revelation and engagement. They were and remain as accessible as a newspaper cartoon. But their simplicity of character is no hindrance to their subtlety of content. They speak in a style as old as the Aztec civilization they allude to and as new as anything under the sun. Drawn by the controversy, honesty, spectacle and excellence of this work, it revealed Detroit to its 
inhabitants as a force of nature that men and women dared govern. In this work the city was mirrored as a furnace of men and machines who made their community out of raw minerals, human strength, cooperation and intelligence. Here was a vision of the faith and the strength that Detroit had to maintain in order to keep on surviving and flourishing. Detroit was a good place to live-accepting the fact that it prospered and grew out of the furrow of its own contradictions.

A sublime complement took place. As Rivera lived and worked in the USA during its period of greatest socio-economic strain, so Edsel Ford's lifetime coincided with Detroit's single greatest period of expansion. They knew two extremes which exposed the nature of the place. Rivera saw the people and the system pushing at its seams, alive with the hope of regaining what they were best at but what they had lost. Edsel Ford had grown up with the reinvention and diffusion of the American car on American soil, Ford Motor Company as the embodiment of this new product. He inherited a sense of pragmatic idealism gained from the visions of his father and developed on his own terms. Helped the US auto industry retool for war, make compromises for the sake of profit and the gradual loss of worker gains in the industry's booming decades, followed by the unprecedented economic downturn of the early 1930s. Diego Rivera's two-year residency in Detroit culminated in their collaborative creation which captured the city and system at the height of its precarious success. Rivera gazed into the men, the city, the industry and saw its soul.

The Detroit Industry Murals sparkle with probes. Its vast visual narrative responds to the question: What if one could get Detroiters to see their dangers and strengths amid their darkest period?

The objective of Edsel Ford and Diego Rivera was not to create social policy but social insight. To erect a set of secular stained glass windows in the cathedral of industry that was Detroit. Rivera always claimed that any art worth its salt must be propaganda. This was meant in the best sense of this term: "rational propaganda in favor of action that is consonant with the enlightened self-interest of those who make it and those to whom it is addressed." Thus propaganda "appeals to reason by means of logical arguments based upon the best available evidence fully and honestly set forth." 98

The Detroit Industry Murals offer a riveting story without words which the viewer can share and carry away in his or her own mind. The public art and popular culture of the Detroit Industry Murals tried to invigorate with sturdy principles and provocative wonder; not lay down the law, that plaything of lawyers. They remain a Declaration of Independence and not a Constitution. The best public art and popular culture provide people with an accessible understanding of what's best, worst, and in need of help within themselves and in their world. It took a few special people-artists and businessmen-to make this happen.

\section{VI}

131 The Detroit Industry Murals consists of twenty seven linked yet separate frescoes, each picture a story in itself, each leading to the next and so on back again in a cycle of discoveries and self-reflections. Diego Rivera's work, and his murals in particular, were 
primum mobile, mainspring and spark plug for the vast new creative engine of the New Deal's Federal Arts project, as historians now widely recognize. ${ }^{99}$ Rivera's mission, as he noted in his autobiography My Art, My Life, was set by Edsel Ford on "only one condition:

that in representing the industry of Detroit, I should not limit myself to steel and automobiles but take in chemicals and pharmaceuticals, which were also important in the economy of the city. He wanted to have a full tableau of the industrial life of Detroit He said good-humoredly that he wished to avoid any impression of partiality toward the industry served by his father and himself. ${ }^{100}$

Franklin Delano Roosevelt was inaugurated as 32nd president of the United States on March 4, 1933. The Detroit Industry Murals opened for public viewing a little over a week later on March 13, 1933. A well-timed sequence of events were unfolding. Ringing in the audience's ears at the Detroit Institute of Art on March 13, 1933, were the freshly-minted words from Roosevelt's First Inaugural Address: "So first of all let me assert my firm belief that the only thing we have to fear is fear itself-nameless, unreasoning, unjustified terror which paralyzes needed efforts to convert retreat into advance." And here were the encouraging images of this advance.

Clear understanding of Edsel Ford's and Diego Rivera's Detroit Industry Murals asks they be put in focus through this historical event: the timely arrival of the New Deal and Edsel Ford's sympathy for Roosevelt's programs. They were not born and given shape in an historical vacuum. And we now know what was not at all well known at the time, that Edsel Ford was a personal supporter and counsellor of Franklin Delano Roosevelt. Edsel Ford became close to Franklin Delano Roosevelt by 1928 and visited Franklin Delano Roosevelt at Warm Springs, Georgia, while Franklin Delano Roosevelt would visit Edsel Ford at his summer home-discreetly, off the beaten track-in Maine. 101

Moreover, both Edsel Ford and Diego Rivera shared a deep faith in what good machines could accomplish in partnership with man. As Rivera wrote about his impressions in Detroit while conceiving his plans for the murals:

I walked for miles through the immense workshops of the Ford, Chrysler, Edison, Michigan Alkali, and Parke-Davis plants. I was afire with enthusiasm. My childhood passion for mechanical toys had been transmuted to a delight in machinery for its own sake and for its meaning to man-his self-fulfillment and liberation from drudgery and poverty; that is why I now placed the collective hero, man-andmachine, higher than the old traditional heroes of art and legend." 102

Sample by example: as you enter the high-vaulted, glass-roofed hall in the Detroit Institute of Arts your gaze turns right to the south wall. ${ }^{103}$ 
South Wall, jungle of steel

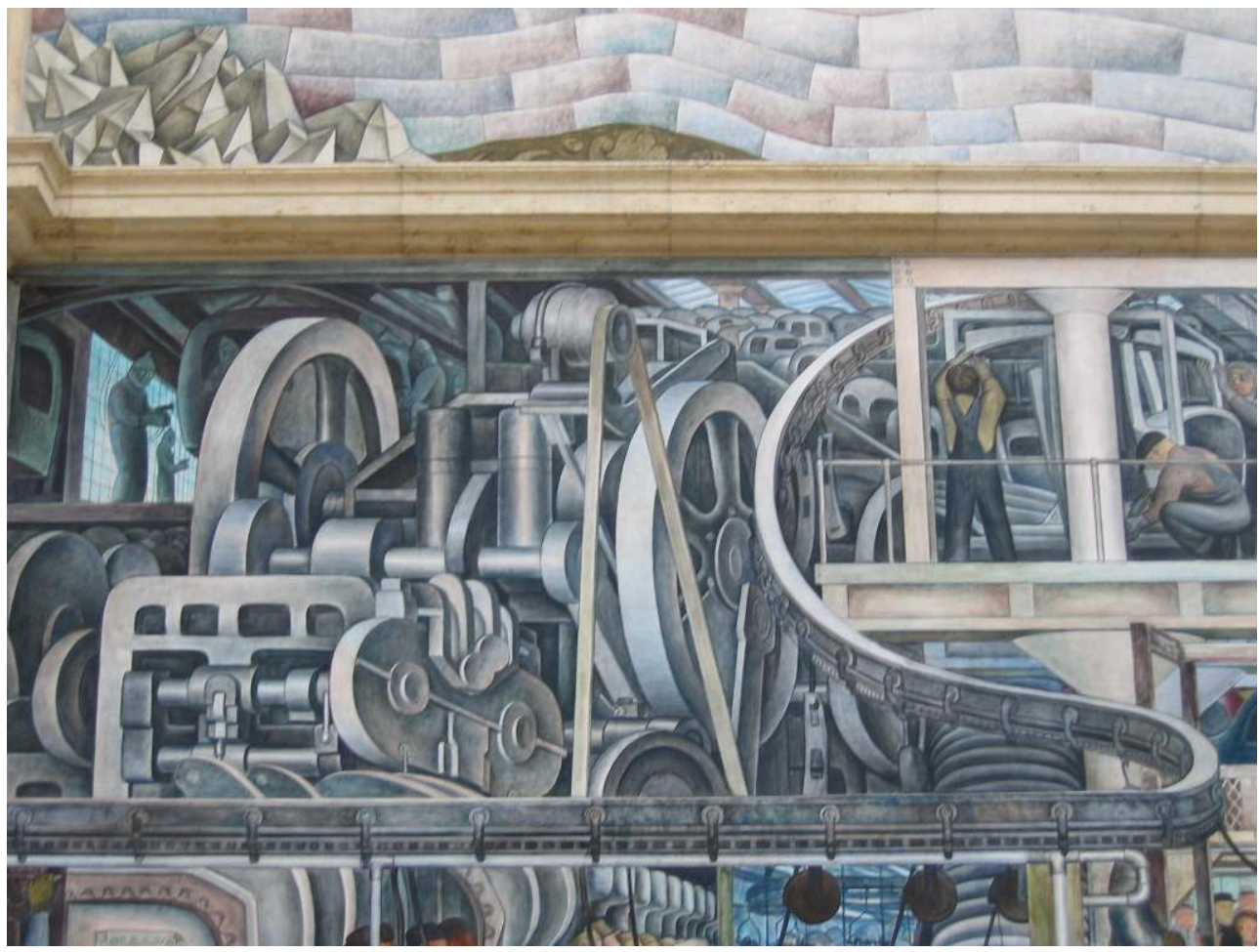

Photo taken by John Dean(

\section{South Wall of the Detroit Institute Murals in the Rivera Court}

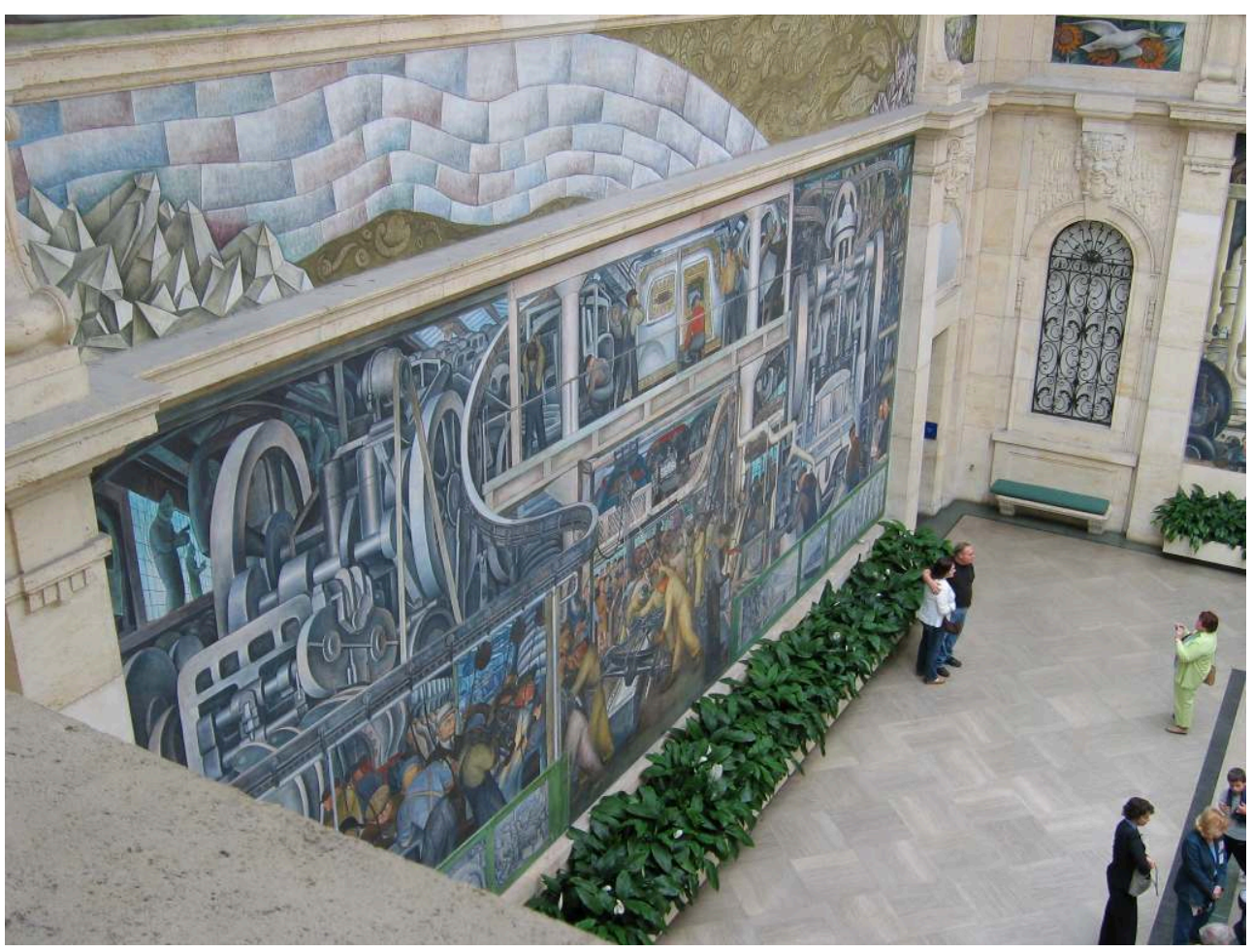

Photo taken from back balcony, by John Dean ( 
Look at it and you enter into a jungle of metal. You're among layers upon layers of machines straight curved and twisted that snake forward with all the parts that go into making up a car. Except that you do not see a car. The twenty-seven panels are joined by "one of the dominant rhythms in the life process-the wave"104; a universal human symbol associated with water, power, ceaseless and independent movement, change, agitation and vicissitude.

Tools and machines are used by hundreds of men who are one-hundred percent concentrating on their individual jobs. They are factory workers of all races, sizes, shapes, muscles and bones. They are seen at an angle, from the side. From where the viewer stands and looks one is not included in the factory. You observe and appreciate the workers who wear safety goggles, masks and hats, are dressed in dark tough overalls and protective aprons. Your own presence matches a clot of men and women observers who stand far back to the right and middle, out of the lines of action.

Here in the factory are men at work and in their work. "You cannot gauge the intelligence of an American by talking with him: you must work with him," wrote US longshoreman-philosopher Eric Hoffer. "The American polishes and refines his way of doing things-even the most commonplace-the way the French of the seventeenth century polished their maxims and aphorisms." 105

These men are doing everything which must be done to make a car. Workers in overalls lift, carry, hammer, drill, yank, pull; they sand knife sheets of sparks off the shells of curved and angular car parts; they fit, screw, solder, click, place, dip, rub, pump, and adjust chunks of metal. It is one continuous sentence, one immense verb. There is no sound. But you hear the noise.

Picture the long whole wall to the right as a scene about means, not ends. This is the assembly line devoted to the exterior of the 1932 Ford V-8 engine at the Ford Motor Company's Rouge factory. Rivera shows three times as many men than those who actually worked the line. And you do not see a car. Or barely.

Unless you shift your eyes and look almost dead center at the fresco. Look down and above the line of beige-suited workmen. Look way back into the tunnel of machinery. See one man with chiselled features, beige overalls, erect posture, high cheekbones, Latino complexion, carrying a steering wheel circle and column with great concentration. Look way back behind him to his left like you were looking down into the bottom of a tubular telescope held upside down. See a little slab of light at the end of the tube. And there's this tiny red dot of a Model A Ford way off in the distance. It is no bigger than a scratch on the stone canvas of the fresco, maybe three inches, ten centimeters long. This negligible object they create. 


\section{South Wall, center}

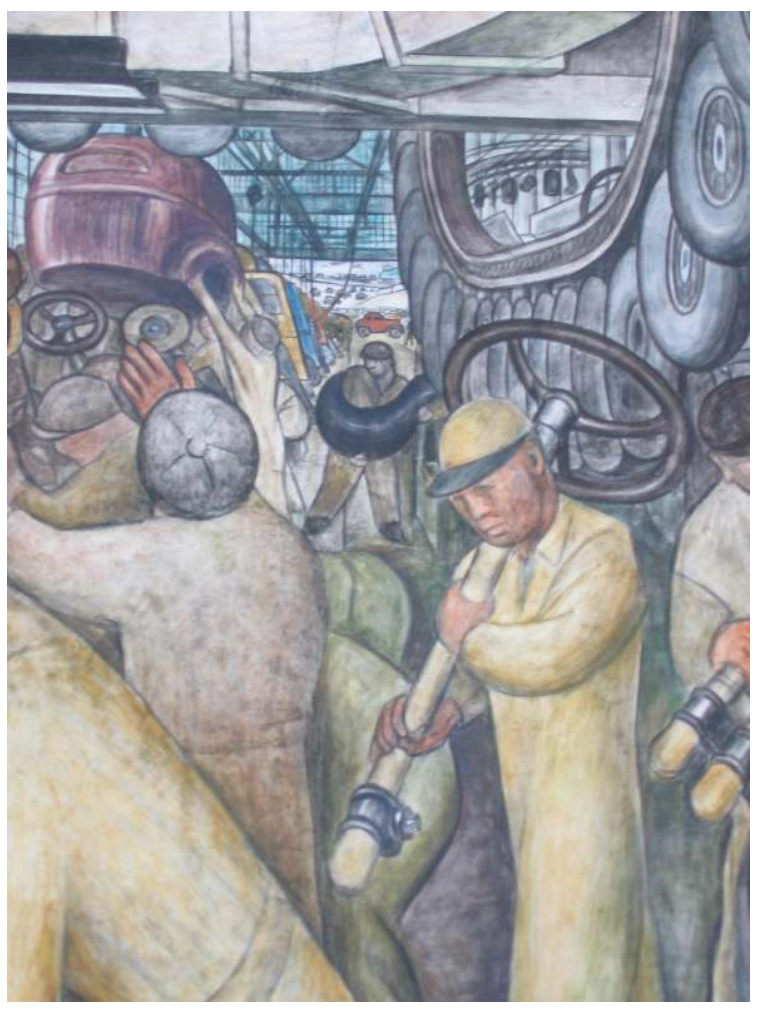

Photo taken by John Dean@ Building (completed 1931) or the greatest automotive totem pole ever constructed, Walter P. Chrysler's Chrysler Building (completed 1930)-were two ever-astonishing, realized visions of modern, material power. Or businessmen would pillar up the classics. Bring Shakespeare back into American life. Which is what Standard Oil president and chairman of the board Henry Clay Folger (1857-1930) did. He left his fortune to build the Folger Shakespeare Library in Washington, D. C.; cornerstone laid on Shakespeare's birthday, April 23, 1932. 
Edsel Ford tackled in his own way how men and women do not live by bread alone. The key was to relate. Together. Only relate. Make art news that stays news.

Probably the most profound, mobile, and universally-accessible spiritual statement of this kind from the heart of the American Great Depression was John Steinbeck's Grapes of Wrath (novel: 1939; movie: 1940). Specially seen and heard in Tom Joad's prayer-talk to Ma Joad at the story's conclusion. When Tom laughs uneasily and says: "Well, maybe like Casy says, a fella ain't got a soul of his own, but on'y a piece of a big one." ${ }^{108}$ And flows on in this rich vein; a story that doesn't end, but continues as a song of hope in the hardest times for the poorest people. And yet it's a story-song for rich and poor alike. Brotherhood is shamelessly inclusive.

What John Ford was to Steinbeck, Edsel Ford was to Rivera. Each gave their artist a bigger canvas, a more visible space to get their message across. The Grapes of Wrath was less of a commercial risk that Rivera's murals. Twentieth Century Fox-Film Corporation, who produced Grapes of Wrath, made far more than Edsel Ford ever did from their investment. In its era the American viewer had been primed for Grapes of Wrath by years of highly visible photos and graphics in newspapers and on posters supplied by the US Farm Security Administration (aka the FSA; which employed Walker Evans, Dorothea Lange, Carl Mydans Arthur Rothstein, and Ben Shahn, among others) and longer visual works publicly displayed, such as Dorothea's Lange's and Paul S. Taylor's An American Exodus. ${ }^{109}$

Rivera's Detroit Industry Murals were recognized by the city's local, left-wing politically engaged-and mainly working class-public, but they came out of the blue for the city's meek middle class and large ultra-conservative groups led by Detroiters such as Father Coughlin and Gerald K. Smith. Among US social-problem films, Grapes of Wrath's box-office gross has been constant over the years and to this day it remains among the top ten to twenty ranked and viewed films of the 1940s. ${ }^{110}$ In contrast, Rivera's Detroit Industry Murals are in the public domain, like WPA and FSA art. They keep producing meaning, but not money. As with Rivera's murals, Ford's Grapes of Wrath was a political risk and questioned by those around him for similar reasons. As Chicago Sun-Times movie critic Roger Ebert's gawky but apt appraisal of Ford's venture noted: here was "a left-wing parable, directed by a right-wing director;" though it's ultimately "a message movie, but not a recruiting poster." 111

Return to the south wall of the Detroit Institute Murals.

Many of the south wall's machines have faces which appear like a surprise, as ambiguous figures-look like at least two things at once on different intersecting planes the longer you look at them. Some machines have eyes, a pan face, a snake body, a head. Each machine of this kind is a predacious thing marked by squat arrogance or a half-body of mouth and gullet, each a creature designated by its physical design for a dominant purpose and hunger. 


\section{Creature machine}

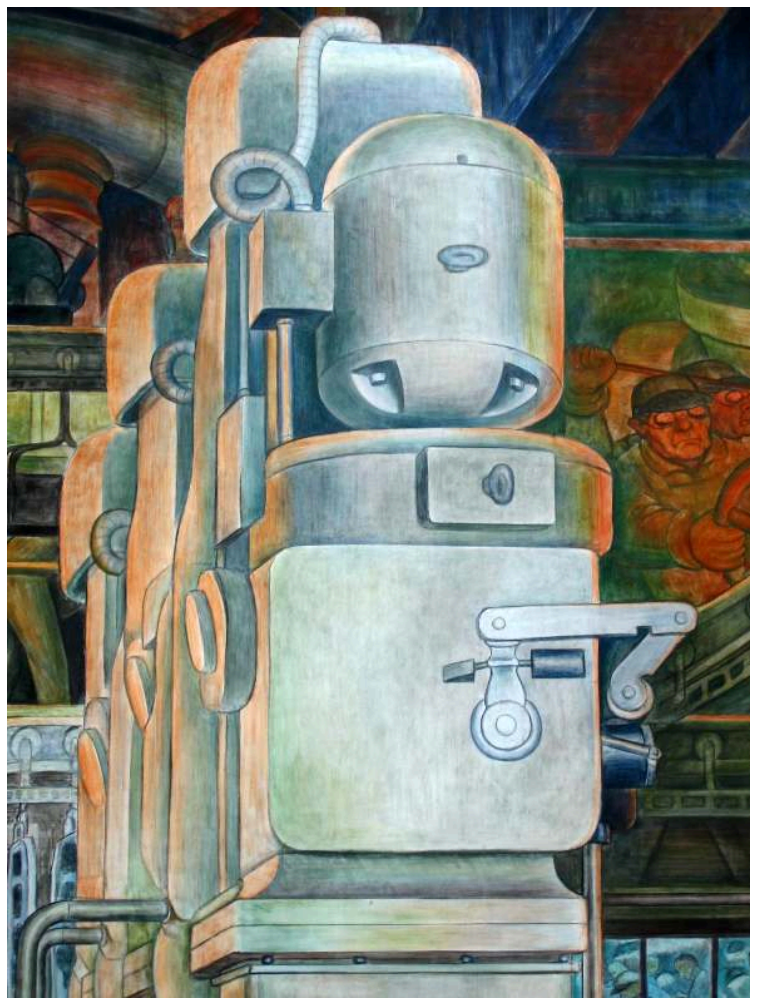

Photo taken by John Dean(

\section{Another creature machine}

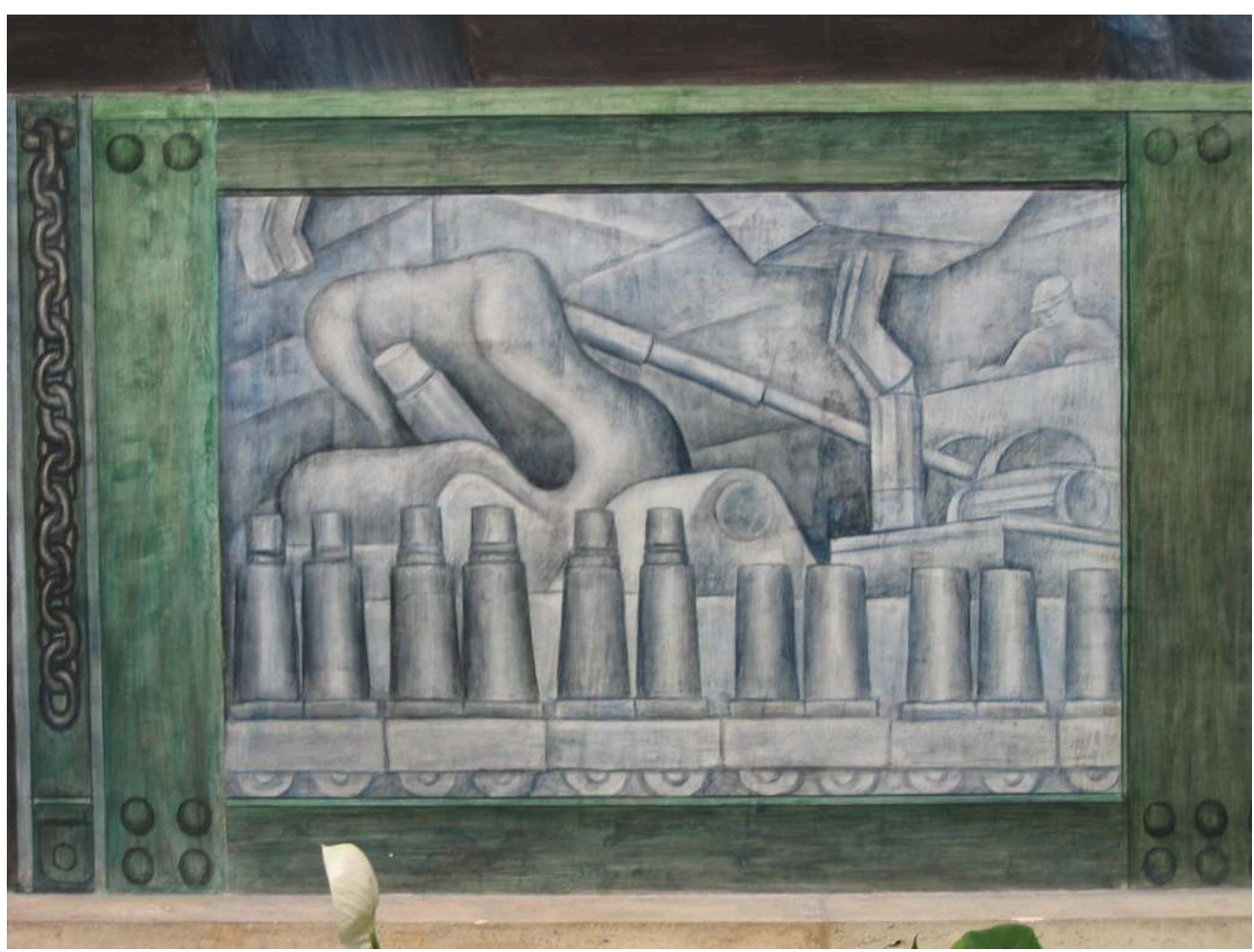

Photo taken by John Dean ( 
One machine specially dominates. The huge squat tall one to the right. See it with the big wheels and the stubby little clover-leaf head. Colored mat grey and smooth surfaced, a huge exteriorized skeleton of a thing. This is the stamping press or drop forge. It's the height of five men. The work of the stamping press is to shape formless metal. Take the raw mud stuff and give it purpose in this industrial Garden of Eden.

This stamping press is also the Aztec god Coatlicue costumed and modernized in a solid robe of gears and levers, nuts, bolts and tubes. She wears a few immaculate chains for her inner necklace, one clean squat fist gut center which squeezes small tons of metal into shape. Up above this stamping press-Coatlicue's head wears a smile that is not a smile, that is a wide slit, an archaic smile of a slit, Aztec strong. She is hungry. She feeds. And she is fed.

\section{Coatlicue}

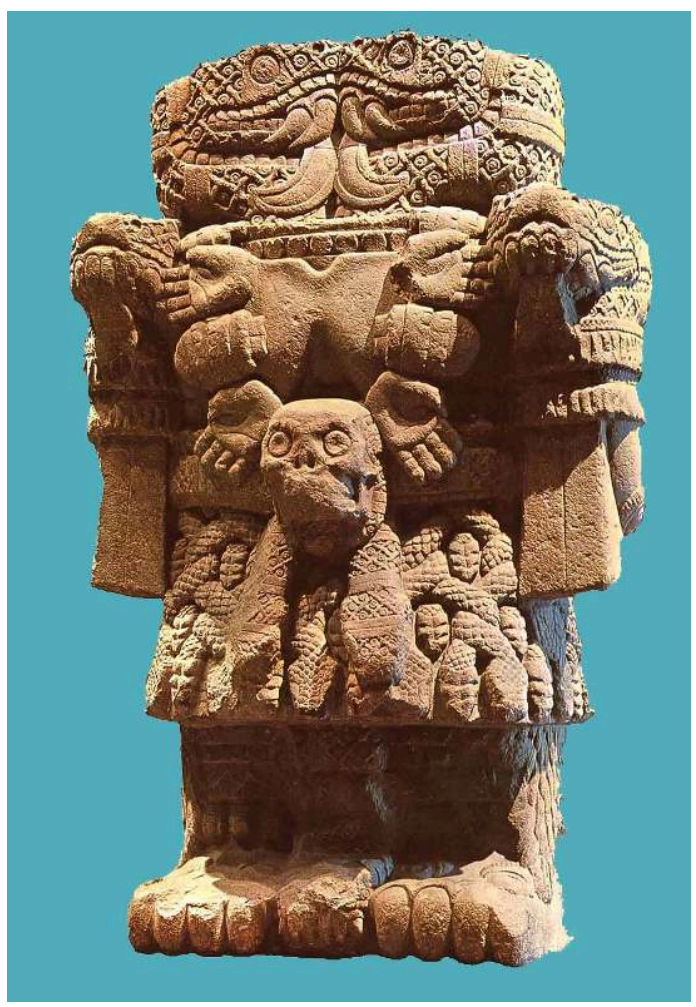

\section{Public Domain, National Museum of Anthropology, Mexico City}

Of all people in the south wall three stand out the most at first glance.

To the left among the workers is the square-jawed foreman. He is probably Mead L. Bricker, one of Henry Ford's chief production assistants. To the far right in profile is the delicate silhouette of William Valentiner, his face a chisel of bones on parchment flesh white and pink as the sky of a Dutch landscape. Herr Valentiner hold in his hands the dedication paper which reads: "These frescoes, painted between July 25, 1932, and March 13, 1933, while Dr. William Valentiner was director of the Art Institute, are the gift of the City of Detroit of Mr. Edsel B. Ford, president of the Arts Commission."

154 Just behind and moving forward from the left of Valentiner stands Edsel Ford dressed in a fine-cut suit of metallic-grey fabric. His face and features are seriously staring out 
and forward. But at what? He is not staring at the viewer. He is looking at something interior. He's reflective, composed. And with absolutely no trace of a smile.

Drop forge-Coatlicue, with Edsel Ford and Valentiner in lower right hand corner

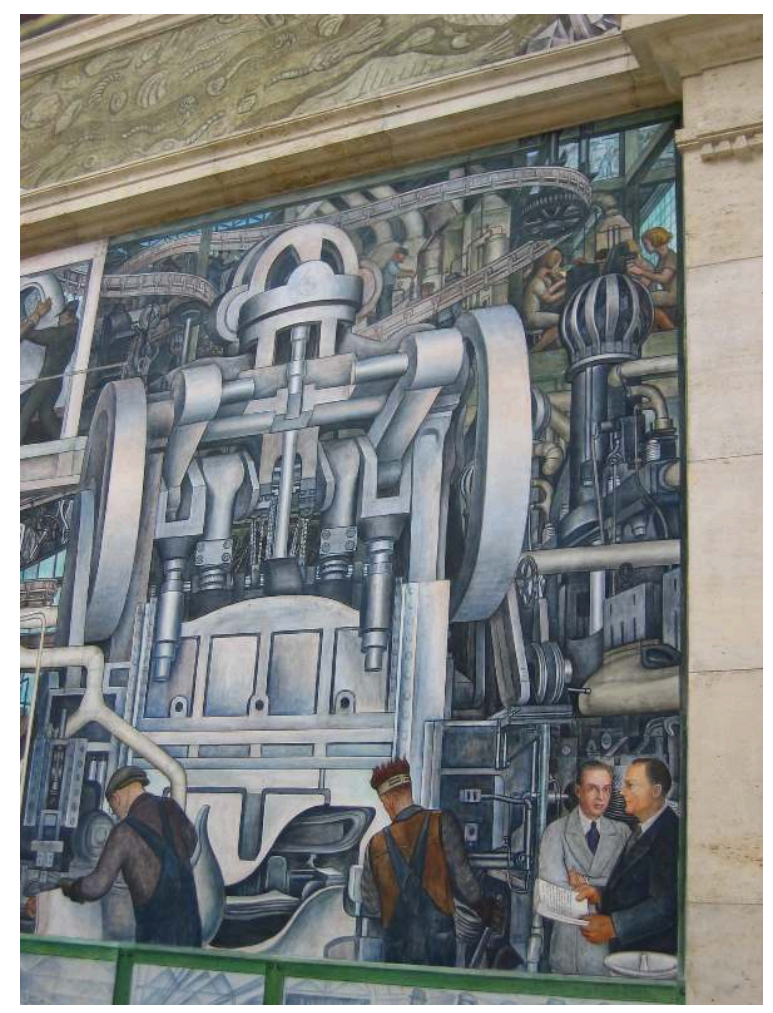

Photo taken by John Dean( 


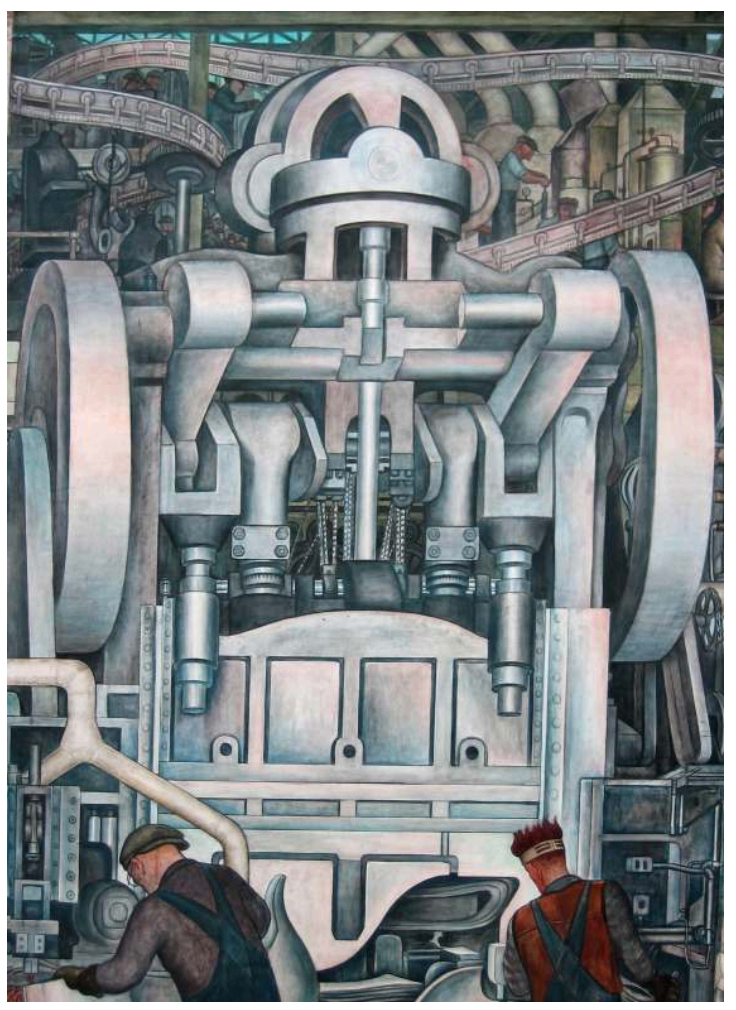

Photo taken by John Dean(

The who and how of what Rivera did here is decisive; the aspect of patronage-in Rivera's sense of patrón-and the fact of fresco.

The Detroit Industry Murals are explicitly a work done in patronage. Rivera leaves no doubt about this when he painted into the lower right hand corner of the south wall panel: Edsel B. Ford, president of the Arts Commission and donor; Dr. William Valentiner, director of the Detroit Institute of Arts. ${ }^{112}$ Rivera was known to have had a specially good relationship with his patrón Edsel Ford. Patrón which in Spanish means much more than in English: patron-protector; patron saint; sponsor; master, boss or proprietor; landlord or host; and patron of the arts. ${ }^{113}$

Rivera did not speak English when he came to Detroit and accepted Edsel Ford as his patrón. As far as we know, they communicated through translators, body language, exchanging sketches, and intuitive, non-verbal communication. Rivera understood the wealth of patronage. Knew well the European tradition of the artist in a royal household. Rivera's ideal was the accommodation of artist and patron. He would speak his own art-speech, but through the grace and understanding of his patrón. Empathetic voices and visions. Achieved, as Valentiner closely noted, when an establishment industrialist and a political radical found they could work "constantly in touch with each other" for the common good of Detroit, the nation, and the future. ${ }^{114}$ This achievement in Detroit was in great contrast to River's next American assignment. Rivera moved on directly from Detroit to New York City, where he was under the patronage of John D. Rockefeller Jr., to create the "Man at the Crossroads Looking With 
Hope and High Vision to the Choosing of a New and Better Future" murals for the new Rockefeller Center. Which project was a "Holocaust in Rockefeller Center" as Rivera entitled this chapter of his life. ${ }^{115}$

He and Rockefeller had no empathy. The exquisite combination of control and creative freedom which Edsel Ford adroitly managed was nonexistent in New York. Rivera and Rockefeller finally fell out over the depiction of Lenin in "Man at the Crossroads". But it was an accident waiting to happen. ${ }^{116}$ So Rivera was paid off by his patrón in New York City, kicked out of the building, and about a year later his almost-completed murals were eviscerated from the flesh of the walls. He also had an assignment with General Motors. But when they heard about what had happened with Rockefeller, GM cancelled. Rivera left the U.S.A.

Edsel Ford had the first word on hiring Rivera, and had the last word on silencing the voices demanding the destruction of the Detroit Industry Murals.

Rivera's patrón Edsel Ford was faithful to him; for which he was revered: "I was gratified that Edsel Ford stood by me loyally," ${ }^{117}$ wrote Rivera. In Rivera's beloved, turbulent Mexico this kind of supportive and instructive patronage happened as an expression of loyalty, trust, and courage. Just as Francisco Madero was patron for Pancho Villa (1878-1923). "This is a rich man who fights for the good of the poor," said Villa about Madero; "and if all the rich and powerful in Mexico were like him, there would be no suffering." $" 118$

163 Edsel Ford would not allow Rivera's work to be touched or altered. As he was loyal to James Couzens, to his father, to his own wife and children, and to his brother-in-law and closest friend Ernest Kanzler, so he held true to this artist. "I admire Rivera's spirit. I really believe he was trying to express his idea of the spirit of Detroit," Edsel Ford declared in public statement when scandal raged for months after the murals were completed and shown to the general public. ${ }^{119}$

What is remarkable is that the Ford-Rivera Detroit Industry Murals are sacred without evoking a single religion. The Detroit Industry Murals are incandescently ecumenical. They are-the englobed vision is-deeply American, North and South. Bigger than one nation. Yet purely Detroit.

As D. H. Lawrence defined this spirit in his 1923 Studies in Classic American Literature, so it is here a short ten years later in Edsel Ford's and Diego Rivera's vision. Look at the workers in these murals. Here "is a new doctrine. A doctrine of life. A new great morality. A morality of actual living, not of salvation." ${ }^{120}$ The Detroit Industry Murals do not espouse the saviourism of $a$ leader, $a$ religion, a god, $a$ political persuasion. Here is "no morality of salvation" but of "the soul living her life, not saving herself". ${ }^{121}$

But not without scandal.

167 As soon as the work began to take shape, Rivera's Detroit Industry Murals caused outrage and delight in Detroit. 
Among the scandals, an outstanding incident was the popular confusion about the Vaccination and Healthy Human Embryo panel of the fresco on the upper right hand corner of the north wall. It's a playful version of a nativity scene. 


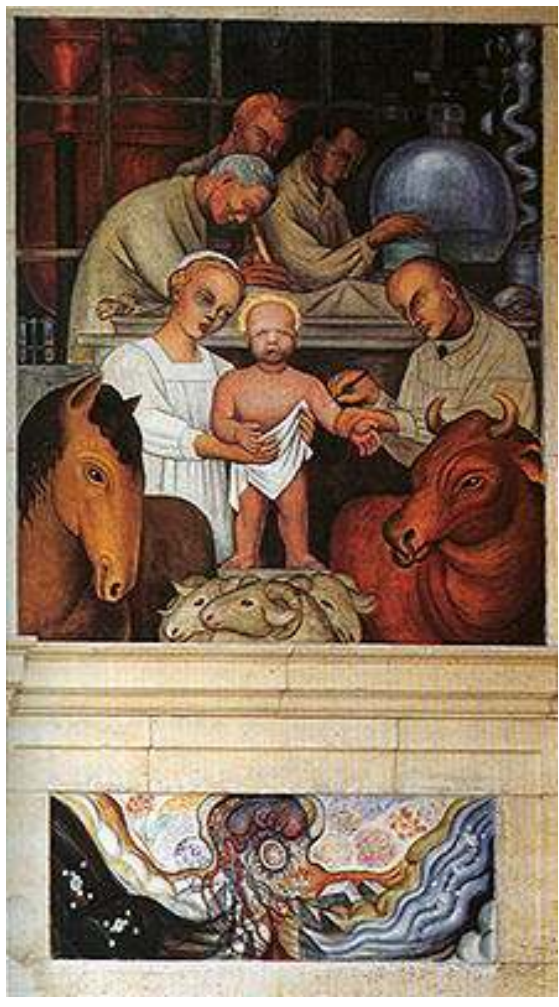

Public Domain, Detroit Institute Murals

But altogether in the American tradition. After all, vaccination in America dates back to and begins with Cotton Mather (1663-1728), Puritan worthy and one of New England's elect saints. Rivera was a man with an embarrassment of knowledge about things technical and scientific.

But for many of Detroit's local church authorities Vaccination and Healthy Human Embryo was blasphemy of the worst sort. Specially upset was Father Charles Edward Coughlin (1891-1979), America's virulent, pro-Nazi, Catholic radio priest of the era who lived and worked in Detroit. As Rivera related in his autobiography:

Father Coughlin began to honor me daily with long diatribes, condemning the Institute frescoes as immoral, blasphemous, anti religious, obscene, materialistic, and communistic. As a result, the whole city of Detroit began to argue about what I was doing. A city councilman assailed my murals as 'a travesty on the spirit of Detroit' and urged his fellow councilman to order that they be washed from the walls. Soon the whole region entered into the melee."126

The Detroit News seconded Father Coughlin's spirited appeal to moral wisdom and editorially declared: "the best thing to do would be to white wash the entire work completely." ${ }^{127}$

Coughlin was no fool. He was brilliant at playing upon the instrument of popular opinion. In Los Angeles in October 1932, only a few months before the Detroit Industry cycle was shown to the public, David Alfaro Siqueiros (1896-1974) a key member of the era's Mexican muralist group, had painted his La América Tropical ("Tropical America") mural in Los Angeles on the second-story, outside wall of Olvera Street's Italian Hall. A center piece of Siqueiros' mural was a crucified Indian peon topped not by a crown of thorns but by a clawing eagle, which could either be seen as a symbol of Mexico or of 
US capitalism. ${ }^{128}$ Within six months this controversial section had been whitewashed over and within a year Siqueiros' whole mural was completely covered. Only recently has this work been redeemed. La América Tropical is now undergoing restoration and is scheduled to be completed and reopened in 2012-2013. ${ }^{129}$ In the late winter of 1933 Coughlin and his associates were hoping to achieve with Rivera's work and Edsel Ford's patronage what had already been accomplished in Los Angeles with Siqueiros's work.

Diego Rivera deeply enjoyed the cause celebre. He was a rebel with a cause. Which was really very simple: show men as they work to improve their lot in the industrial age. As Albert Einstein said: "Everything should be made as simple as possible, but not simpler." My objective in these murals, wrote Rivera, "was to represent the life of an age which had nothing to do with baroque refinements-a new life which was characterized by masses, machines, and naked mechanical power." ${ }^{130}$

Valentiner detailed one incident which clarifies much; how many religious extremists felt these barbarous Mexican murals were blasphemous; how specially upsetting was the Vaccination or Nativity panel. It was abusive, irreverent, and unforgivable. But for Rivera vaccination was a sign and celebration of progress. Save the sacred. Save the children.

One day a prominent religious figure from a nearby church rushed into the central court where the new murals were displayed. He knew what he was heading for. Went right up to the Vaccination or Nativity panel. Grabbed Dr. Valentiner and proclaimed: "This! Patterned after the model of the Bible story! And used in a blasphemous manner!" Unforgivable. The man whispered: "The Nativity."

Valentiner tried to explain calmly that what he saw before him here was a common motif in Western art. There were many versions of children with helpful figures. And what one had here was a child with a nurse and a doctor

Then Rivera appeared.

"What is the matter?" he asked.

The minister exclaimed: "Why has the child a halo around his head?!"

And Diego Rivera replied reverently: "Because all children have halos around their heads." ${ }^{131}$

Conspicuous by virtue of their absence in the twenty-seven different pictures of the Detroit Industry Murals are at least a half-dozen outstanding pillars of conventional wisdom. Rivera was optimistically confounding and reevaluating the standard criticisms of many values which Detroit supposedly stood for.

Since Edsel Ford worked closely with Rivera throughout the whole creative process, kept his own presence hidden behind the arras (as noted: a single photograph of the two together has never been seen), paid for the vast majority of the whole work and openly approved it following its general showing to the public directly following Franklin Delano Roosevelt's first inauguration as President on the United States-one cannot help but think that here resides a fascinating reservoir of combined selfreflections.

Measure these by virtue of what is not said or praised in the Detroit Industry Murals, and one finds the conspicuous absence of: 
Fordism. ${ }^{132}$ There are no images of high wages and rising levels of consumption in exchange for harder work and increased productivity. The ironclad cycle of mass production and mass consumption, ever-cheaper, standardized products for everexpanding, homogeneous markets is not here. Industrial development as portrayed here had modified the older "presumption that the dependence of the poor and the responsibility of the rich are the valid moral rules of the social order." 133

The murals were also participating in a larger, contemporary, international debate about Fordism. The cultural climate, the politics, and the economic crisis of the early 1930s bred a great deal of utopianism, the urgent search for a perfect world in the aftermath of the failed promises and lost investments of human lives and fortunes in the first two decades of the $20^{\text {th }}$ century. The early 1930 s also bred dystopias, one of the most enduring and effective vision was Aldous Huxley's Brave New World, written in 1931, first published in England and the USA in 1932, and explicitly directed against the human and industrial engineering models of Henry Ford. Brave New World began with the scathing lines in the "year of our Ford 632", the " $\mathrm{T}$ " of Ford's Model T was seen as a castrated Christian cross with its top lopped off, Henry Ford was a surrogate God figure, the dystopian leader, once on an average of every three pages in the story. ${ }^{134}$ Brave New World was a scandal when published, heavily criticised, and hence very well known. It is also known as a fact that Eleanor and Edsel Ford were heavy readers, had large parcels of books delivered to their house weekly, very much kept up with current cultural trends. All the circumstantial evidence points to the fact that Huxley's dark vision was known by them and hence possibly addressed and redressed in the Ford-Rivera frescoes.

Taylorism. Scientific management as created by Frederick William Taylor (1856-1915), as favored by managers as diverse as Vladimir Ilyich Lenin (1870-1924) and Henry Ford is lacking. Workers are not reduced into robots by functional foremanship or driven by immediate gratification needs. This is not a depiction of "cow sociology": happy cows produce more milk.

187 Natured Conquered. In the Detroit Industry Murals nature is not a force people fight against but a power which must be worked with. On the south wall to the right as you enter, nature embodied in Coatlicue dominates in the guise of the drop forge towering above Edsel Ford. Coatlicue is "the dynamic principle, which no amount of sacrifice can satisfy", nature's principle: eternally crushing to create anew. ${ }^{135}$

188 Coatlicue herself died and was reborn. She was lost, buried, at the time of the Spanish conquest, then recovered around the mid 1800s. Coatlicue's rough equivalent in the Western Classical, Greek pantheon of gods would be elements of Gaea, the primal mother earth goddess, and Athena-a very male goddess of strategy, wisdom and warfare. In Christian mythology would any holy figure dare be like this among the holy ranks-except for Lilith or Tubal Cain?

The narrative of the Detroit Institute Murals depicts ecologically vertical integration from the bounties of earth through the products of mankind. Nothing could be farther from the standard man-versus-nature sermon, the standard man-must-subdue-natureto-prosper belief that dominated American life, action, and industrialization after the US Civil War (1861-1865) and well through the Roaring 1920s. ${ }^{136}$

190 And why do these pictures in fresco? Why not tell this story in a more modern medium, less primitive, less primal? 
191 Fresco is bonded to the wall in a public area. Like poster art or graffiti or a billboard that does not go away. The inter-war years in the United States were an intense, visually active period. More so and different from our current period. People did not then wait or expect for images to come to them. They went out and pursued pictures. On American streets poster art was a major form of public communication. In their newspapers and magazines photography and hand drawn sketches pleasantly mixed. Americans then of all classes, races, religions pursued their images.

When it is done well, a fresco, a mural, gets better with time. You want to go fishing in it. It ages visually like good wine. "A mural only appears to disclose itself at a glance. Actually, its secrets require a long, patient look, an examination which does not wear itself out, not even in the space of the mural, but which extends to all those who prolong it." ${ }^{137}$ It is a slower visual art than what we have grown use to in our age of immediate communication and automatic satisfaction. A mural is not a disposable commodity.

The Pursuit of Happiness. All things considered these murals are a set of tough-minded, realistic images. No one smiles. (Neither, for that mater, does anyone in Michelangelo's Sistine Chapel frescoes, 1508-1512.) What bestselling US author and Methodist preacher Norman Vincent Peale celebrated as the all-American "happiness habit [...] happy thinking," that ability to ever think positive, to arise and say out loud every morning: Yes-" "This is the day which the Lord hath made; we will rejoice and be glad in it"'-is not in the Detroit Industry Murals. ${ }^{138}$

Laborers are not happy worker bees. Emotional complications are not solved. The south wall's stern, paternal foreman (probably Ford production assistant M. L. Bricker, aka: "Brick") glares out at the viewer with his gimlet eyes. On the north wall the cluster of workers-labelled as Bulgarian, Texan, Mexican, Canadian, German, Yankee, Negro, Japanese and Swede by Rivera-muscle the production of the V-8 engine onward with stern dignity. ${ }^{139}$ 


\section{View of North Wall from back balcony}

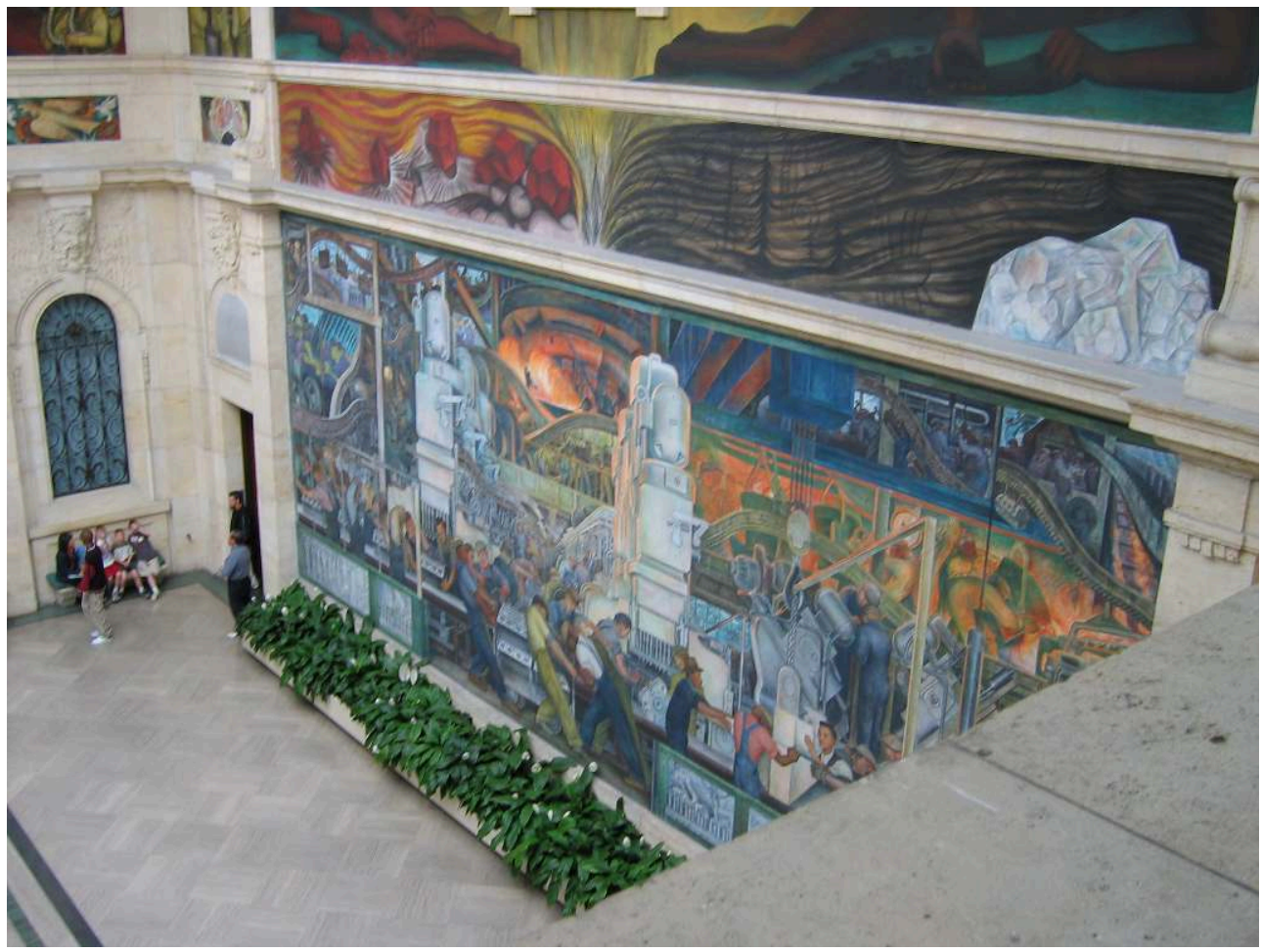

Photo taken by John Dean`

\section{Core of workers on North Wall}

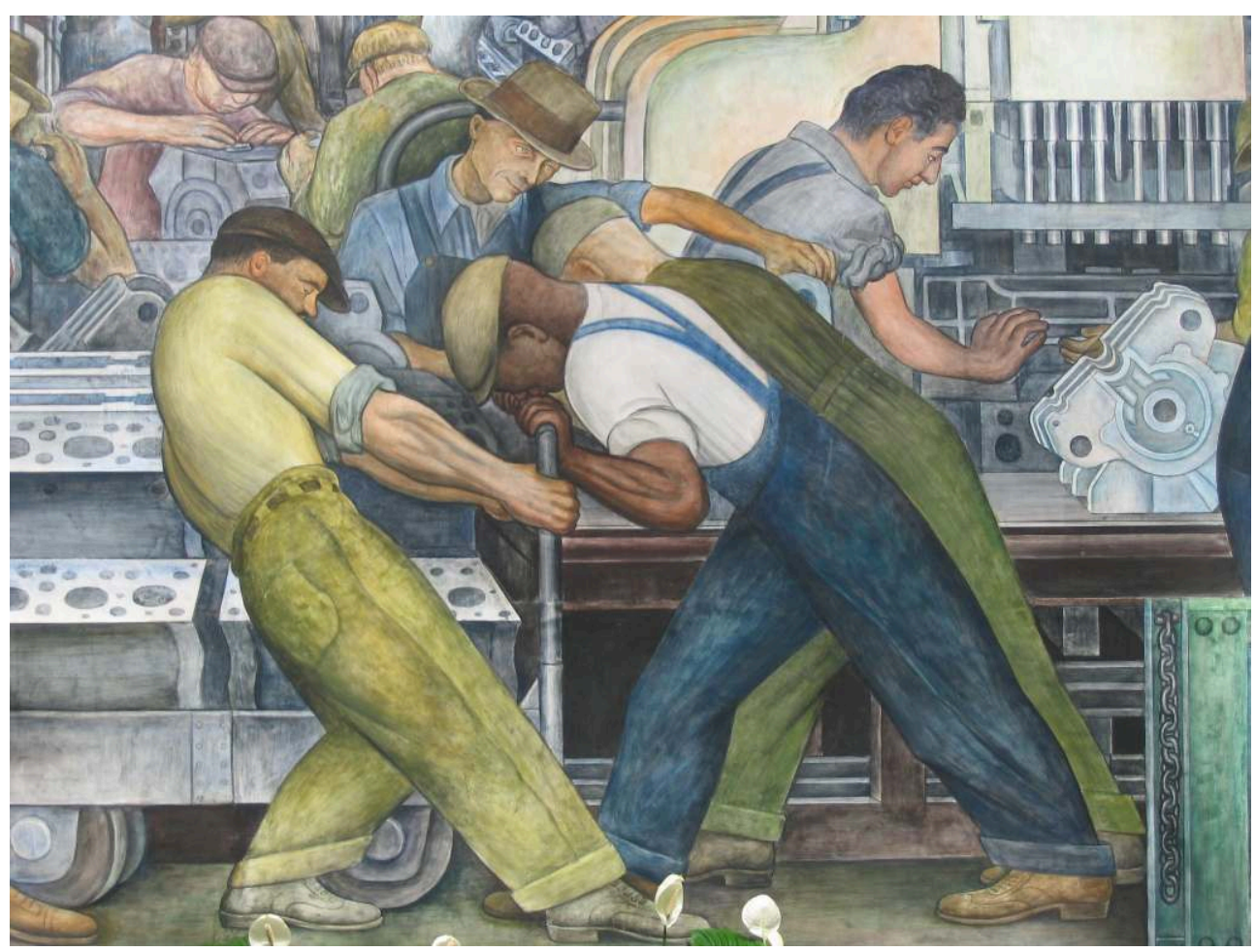

Photo taken by John Dean( 
Likewise in the far lower left grey-blue predella panel of the north wall and the far lower right predella panel of the south wall men and women arrive and depart from work with grim determination. They are a wreck. But they have to go to work.

Men and women trudging home after a hard days work at the factory

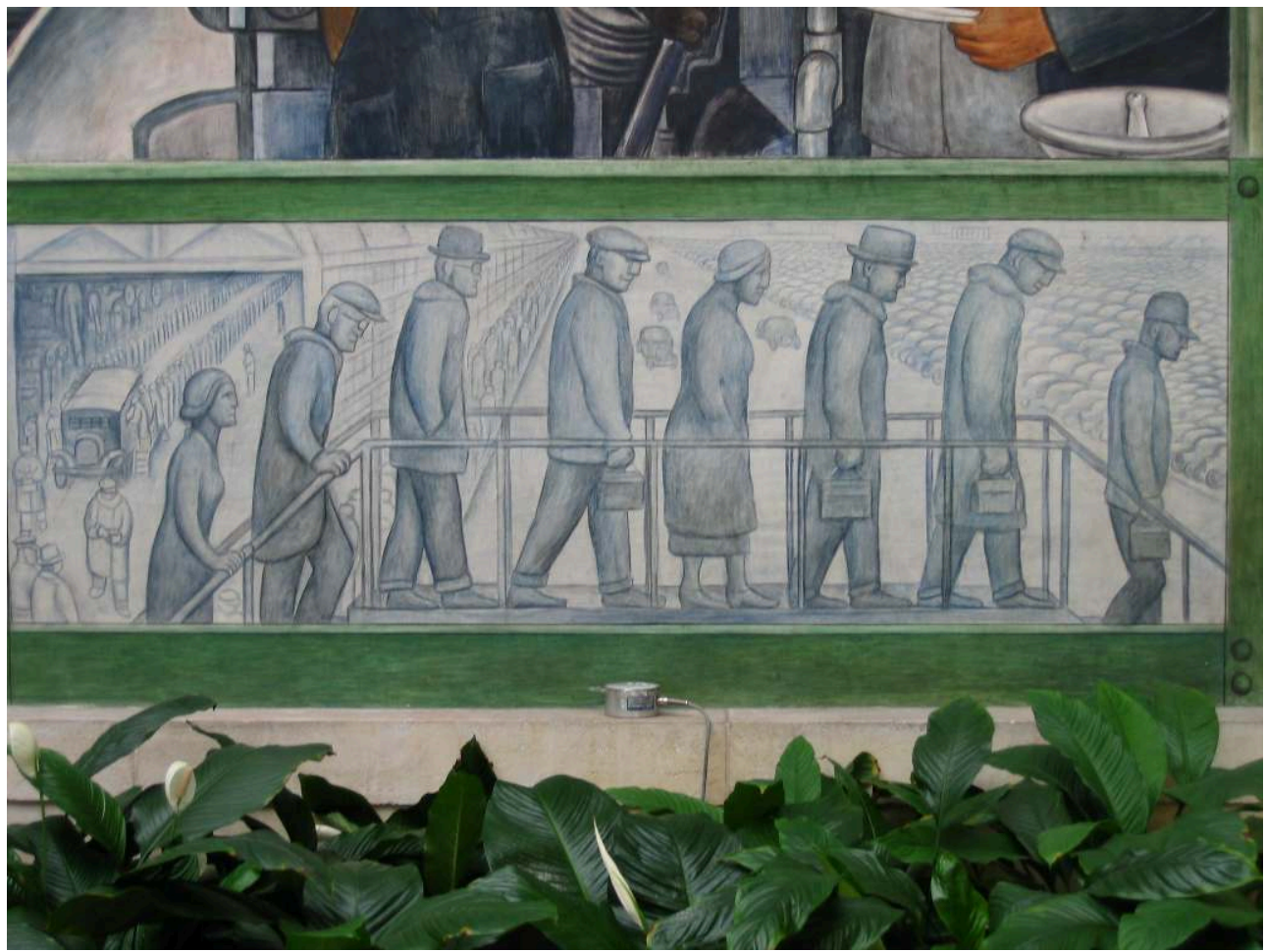

Photo taken by John Dean() 


\section{Workers clocking in to the factory}

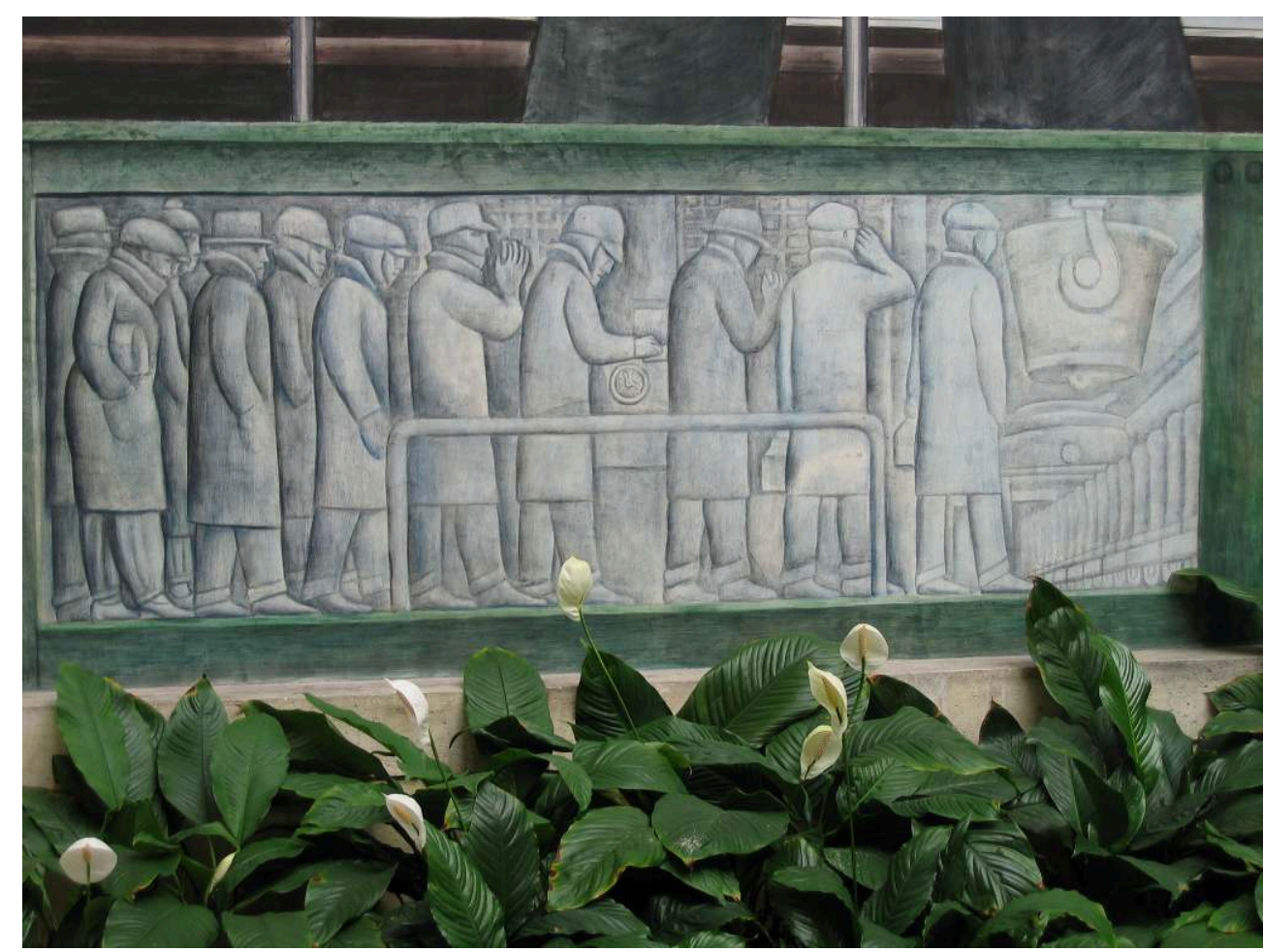

Photo taken by John Dean(

Pure Fantasy. This is not illusory appearances or day dreams based on desires. This is Rivera's idiosyncratic version of realism: "positive, denoting toughness, down to earth attitudes to life or death and a practical outlook on the way things should be managed." A realism which in addition offers for the artist the "great advantage of ubiquitous subject matter. Anything that actually happens or exists"-be it priest-like Henry Ford instructing a hunched group of workers about the V-8 engine or a shapely, full-bodied woman sorting pills ever so near to the gargoyle fat-headed managing chemist in the south wall pharmaceutics panel-“is seen as worthy material." ${ }_{140}$ 


\section{Henry Ford instructing workers on the new V-8 engine}

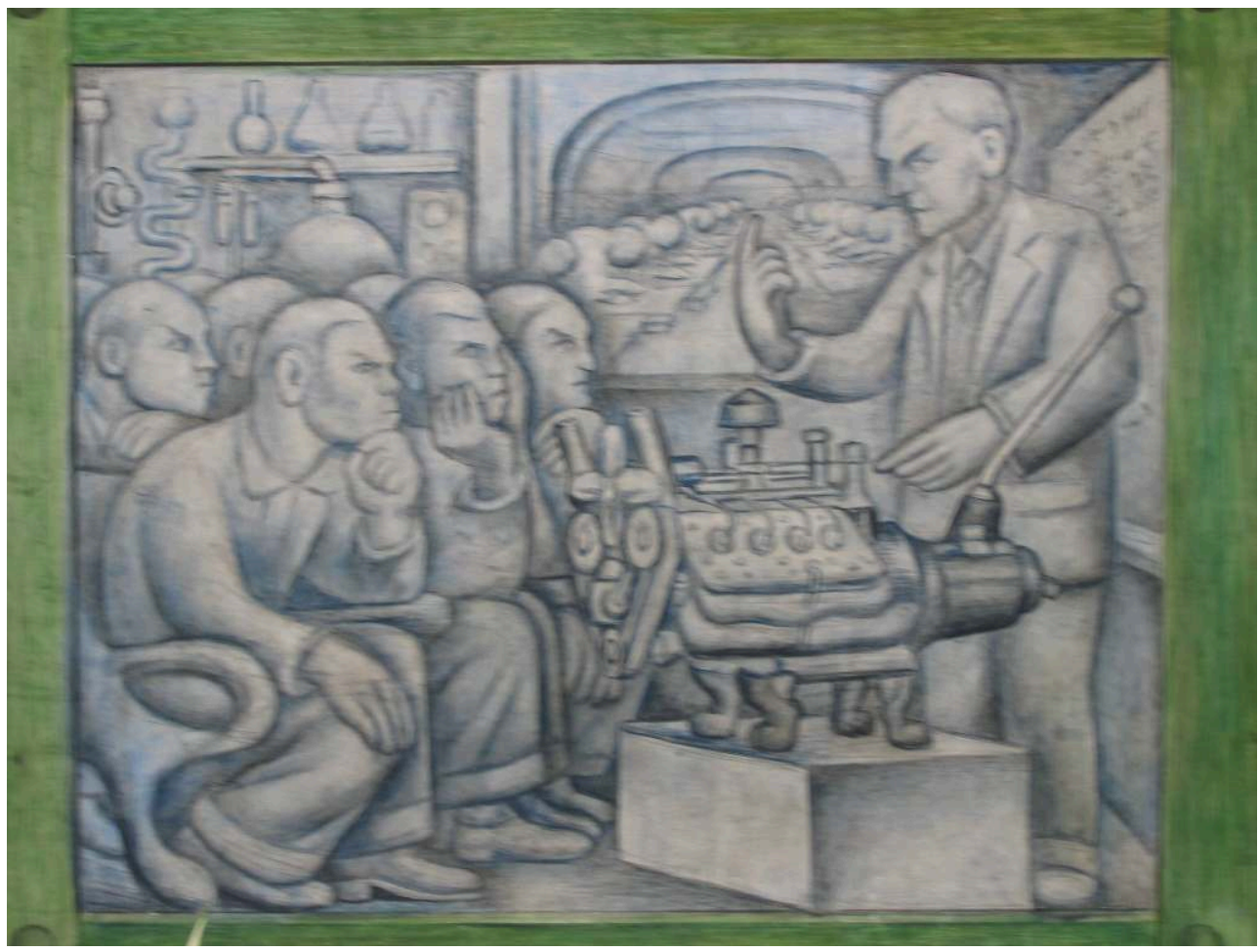

Photo taken by John Dean`

Pharmaceuticals panel, South Wall

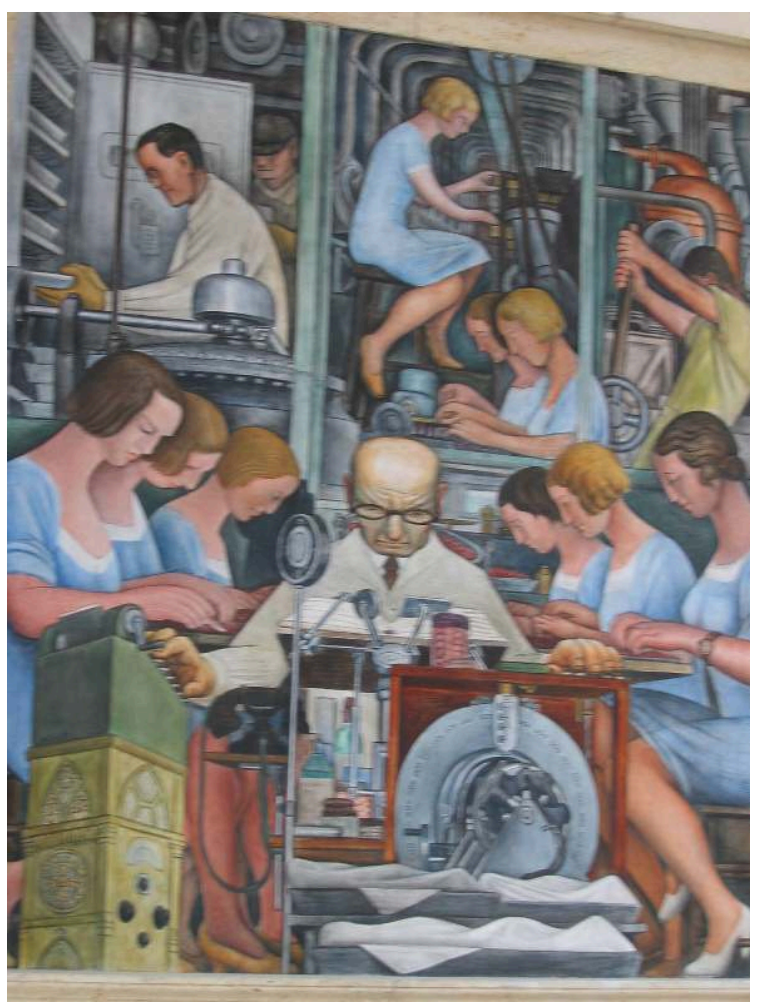

Photo taken by John Dean( 

course, but a vastly overrated and cynical depiction of both industrialization and unions. In cinematic reference, Fritz Lang's Metropolis (1927) offers far more fruitful comparisons to the Detroit Industry Murals. The north and south walls of Rivera's murals are a much more genial, stoical and manly version of a factory compared to the hysterical opening factory sequence in Fritz Lang's Metropolis (1927). ${ }^{146}$ But they do compare. Unlike Lang, Rivera's workers are not spiritually exhausted, scalded to death and consumed by Moloch, and Rivera's factory is not set to explode. However, in place of Moloch another deity looms over men's industry. Coatlicue is natural, but she is not kind. The implicit, utopian Marxism of Lang's Metropolis is replaced by a visionary tragic inevitability in the Detroit Industry Murals. It is not surprising that some of Detroit's Christian authorities of the time wanted these murals destroyed. Their wisdom is primal, provocatively pre-Christian. 

created. considering.

In conclusion, nothing had been done in the United States of this magnitude and this public nature until Edsel Ford's and Diego Rivera's Detroit Industry Murals were

More than any other work of its kind in its time, with Rivera's Detroit achievement Edsel Ford provided a gateway for FDR's New Deal Federal Arts Project established in 1935 within the Works Progress Administration. But why were these murals misread or underestimated for so long? The Detroit Industry Murals were neither a failure of "tolerant dilettantism" nor "a protest against capitalism [and] a protest against industrialism," as a critic contended as late as $1969 .{ }^{147}$ Here was a visionary alliance. Underclass and overclass in union; a harmony of agrarian and industrial cultures; Rivera the bohemian, radical fantastico in prosperous association with Edsel Ford the enlightened industrialist.

Previous works of public art in America bear little or no comparison in terms of social scale, social engagement, holism, and general public exposure. It is not to be found in the conflict, chaos, and misery of Jose Orozco's Mexican mural work in the United States, nor in the surrealistic social realism and oneric hauntings of David Siqueiros' best Stateside work. It is matched by nothing Charles Dana Gibson's Committee of Pictorial Publicity achieved under the federal government's Committee on Public Information, run by George Creel, during World War One. Or by the later achievements of the Gibson Committee in New York City.

The way of the mural in that time and place was "an economic and artistic answer to the American artist's dilemma." ${ }^{148}$ And a way to successfully transmit popular culture at its best. As the genre developed, mural painting wasn't expensive; appropriate spaces multiplied quickly under the Works Progress Administration; public space became congenial place of common, non-commercialized communication. ${ }^{149}$

Ford's patronage, Rivera's work, their unique partnership shows why a "museum is a citadel of civilization," and "not a collection of curious and interesting objects"; how a museum, a monument, a vast fresco can "become an integral part of our democratic institutions"-and how "art in America has always belonged to the people and has never been the property of an academy or a class" 150 -as Franklin Delano Roosevelt declared on radio, May 1939, soon after Edsel Ford has just spoken on the same show.

In sum, Edsel Ford's creative facets were many. Business meant more than dollars and cents. It's a poor business that does not show a profit, but cash alone is not the profit. Along with Edsel Ford's partnership with his wife Eleanor Clay Ford, his own father and mother, the Ford Motor Company, his smoky home town city of Detroit and the clear skies of his Grosse Point Shores home-his legacy of businessman as artist is well worth 


\section{Edsel Ford (1893-1943)}

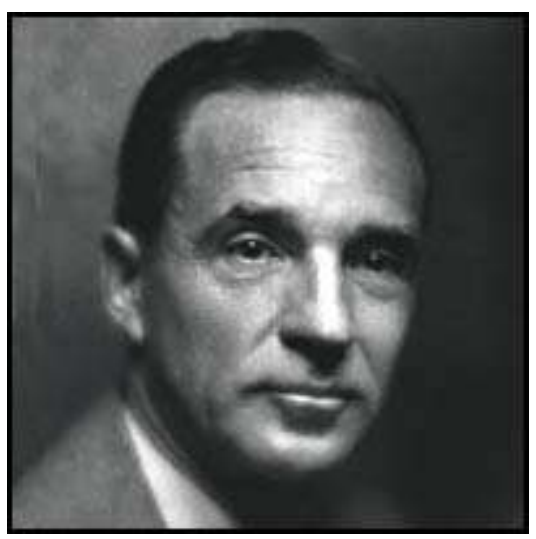

(c) Edsel \& Eleanor Ford House, Grosse Point, MI., used with permission.

\section{BIBLIOGRAPHY}

ANGELO, Frank, Yesterday's Detroit, Miami, Florida, E. A. Seemann Publ. Inc., 1974.

ANONYMOUS, “Auto Men Join Ford in Guardian Trust,” The New York Times, June 9, 1925, 34.

ANONYMOUS, “Corporations: Death \& Taxes,” Time Magazine, June 7, 1943, 81-82, 84, 86.

ANONYMOUS, “Diego Rivera”, Detroit Evening Times, March 21, 1933.

ANONYMOUS, "EDSEL BRYANT FORD” [framed by a double role of typed asterisks], from the Collection of The Henry Ford, Benson Ford Research Center, Acc \# 1, Box 19, File 19-16.

ANONYMOUS, “Edsel Ford Tops the List of 10 Best-Dressed Men," Detroit News, November 29, 1935, reprint of anonymous AP article, same day.

ANONYMOUS, Eleanor Lambert (1903-2003), obituary : "Fashion impresario" dies at 100" in Town \& Country, January $1,2004$.

ANONYMOUS, “Ford's Own Inquiry Led to His Apology," The New York Times, July 12, 1927, 12; based on New York Times research and Jewish Telegraphic Agency articles.

ANONYMOUS, “Guardian Trust To Open,” The New York Times, July 8, 1925, 28.

ANONYMOUS. Michigan: A Guide to the Wolverine State, compiled by workers of the Writer's Program of the Works Project Administration in the State of Michigan. Washington: Library of Congress, 1941, $1971 \mathrm{rpt}$.

ANONYMOUS, “Mr. Justice Brandeis Memorandum," Jewish Telegraphic Agency October 13, 1920, 2. ANONYMOUS, New York Times citing the Jewish Telegraphic Agency in: "Ford's Own Inquiry Led to His Apology," The New York Times, July 12, 1927, 12.

ANONYMOUS, “Side Remarks," Detroit Free Press, Saturday, December 30, 1893, 4.

ANONYMOUS, “The People Crunch,” The Economist, Vol. 390, No. 8614, Jan.17, 2009, 51-53. 
ANONYMOUS, “Twenty Years With Ford," New York Times, March 1, 1933, 4 [NB: E.G. Liebold, Henry Ford's highly opinionated \& powerful personal attorney.]

ANONYMOUS, Typed draft of The Grosse Pointe Guide, The Federal Writer's Project, circa. 1940, special collection-Local History Archives: Grosse Pointe Public Central Library, Central Branch, 10 Kercheval Avenue at Fisher Road Grosse Pointe Farms, MI 48236 USA.

BACON, Irving R, The Reminiscences of Mr. Irving R. Bacon, Vol. II, 169, FMCOH, 1952.

BAK, Richard, Henry and Edsel: The Creation of the Ford Empire, Hoboken, NJ, John Wiley \& Sons, Inc.: 2003.

BALDWIN, Neril, Henry Ford and the Jews: The Mass Production of Hate, New York, Public AffairsPerseus Books Group, 2001,.

BEHR, Schulamith, Expressionism, London, Tate Publishing, 1999.

BEHRMAN, S. N. Duveen, The Intimate Portrait of a Fabulous Art Dealer, New York, Harmony Books, 1982.

BENDIX, Reinhard, Work and Authority in Industry: Ideologies of Management in the Course of Industrialization, New York, Harper \& Row, 1963.

BERNSTEIN, Herman, The History of a Lie: "The Protocols of the Wise Men of Zion", New York, J. S. Ogilvie Publishing Co., 1921. repr. 1972.

BOLKOSKY, Sidney, Harmony \& Dissonance: Voices of Jewish Identity in Detroit, 1914-1967, Detroit, Wayne State University Press, 1991.

BRIDENSTINE, Hames A., Eleanor \& Eleanor Ford House, ed. Cynthia Jo Fogliatti Woodlawn, Maryland: Wolk Press Inc.- Edsel \& Eleanor Ford House, Grosse Pointe Shores, Michigan, 1988.

BRYAN, Ford R., Beyond the Model T: The Other Ventures of Henry Ford, Detroit, Wayne State University Press, 1997.

BRYAN, Ford R., Clara: Mrs. Henry Ford, Dearborn, Michigan, Ford Books, 2001.

BRYAN, Ford R., Henry's Lieutenants, Detroit: Wayne State University Press, 1993.

BRYAN, Ford R., Rouge Pictured In Its Prime, Dearborn: Ford Books-Wayne State University Press, 2003.

BUSTARD, Bruce I., A New Deal for the Arts, Washington, D. C., National Archives \& Records Administration- Seattle, University of Washington Press, 1997.

CARLYLE, Thomas, "Signs of the Times", Edinburgh Review, No.98, 1829.

CASTILLO, Carlos, BOND, Otto F., The University of Chicago Spanish Dictionary, New York: Pocket Books-Simon \& Schuster, 1977.

CLARK, Kenneth, Civilization: A Personal View, London: Penguin, 1969.

COHEN, J.M., COHEN, M. J., The Penguin Dictionary of Quotations, London, Penguin, 1960.

DAVIDSON, Abraham A., Early American Modernist Painting: 1910-1935, New York, Harper \& Row, Publs., 1981.

DELILLO, Don, In Dallas, 1988, Originally published as: Don DeLillo “American Blood: A Journey through the Labyrinth of Dallas and JFK" in Rolling Stone (December 8, 1983).

DOMINGUEZ, Henry, Edsel Ford and E. T. Gregorie: The Remarkable Designs Team and Their Classic Fords of the 1930s and 1940s, Warrendale, Pa., Society of Automotive Engineers, inc.: 1999,. 
DOMINGUEZ, Henry. Edsel: The Story of Henry Ford's Forgotten Son (Warrendale, Pa.: Society of Automotive Engineers, Inc., 2002).

DYLAN, Bob, Chronicles. Volume 1, London, Simon \& Schuster-Viacom, 2004.

DE BONNAFOS, Edith, ["On the Art of Diego Rivera"], "Grandes Choses, il ne faut pas être audessus des Hommes: il faut être avec eux" (Montesquieu)" in Diego Rivera, No. 91 in Hachette series "Chefs d'oeuvres de l'art”, Paris, Hachette, 1968.

DOWNS, Linda B., The Detroit Industry Murals, New York, Detroit Institute of Arts-W. W. Norton \& Co., 1999.

DUNBAR, Willis F., Michigan: A History of the Wolverine State, Grand Rapids, Michigan, W.B. Eerdmans Publ. Co., 1965.

FARBER, David, Sloan Rules: Alfred Sloan and the Triumph of General Motors, Chicago, University of Chicago Press, 2002,

FAIRBANKS, Douglas Jr., The Salad Days: An Autobiography, London, William Collins-Fontana, 1989; orig. publ. 1945.

FERGUSON, Eugene S. « The Minds Eye: Non-Verbal Thought in Technology ». Science 1977 (4306): 827-836.

FIRCHOW, Peter Bernfried Nugel, Eds, Aldous Huxley: Modern Satirical Novelist of Ideas (Berlin: LIT Verlag Münster-Hamburg-Berlin-Wien-London-Zürich, 2006).

FORD, Edsel-A. J. Lepine [EF's personal secretary] response to Miss A. H. Stanton, Art School of the Detroit Society of Arts and Crafts, Dec. 19, 1932; Acc. 572, Box 5, Folder 8.2, Family, The Benson Ford Research Center-The Henry Ford Museum.

FORD, Henry, with Samuel Crowther, My Life and Work, Garden City, New York, Doubleday, 1923.

Ford International Weekly, The Dearborn Independent, Dearborn, Michigan, Jan. 11, 1919, masthead.

Ford International Weekly, The Dearborn Independent, Dearborn, Michigan, May 22, 1920, front page article.

FRANKLIN, Dr. Leo M., "Ford The Suppliant versus Ford The Sinner," Detroit Jewish Chronicle, July 27, 1927.

FRANKLIN, Dr. Leo Morris, Some Untold Tales of Detroit and Detroiters [Unpublished, limited-access restricted manuscript, 1947]; Detroit-Bloomfield Hills, Temple Beth El-Franklin Archives, Leo Franklin: 1870-1948; Rabbi Temple Beth El, Detroit 1899- 1941.

FREEHOF, Dr. Solomon B., “Zionism and the American Jew," lecture, Sunday March 13, 1927, Chicago Illinois, published under the auspices of the K.A.M. Men's Club, 14.

FUENTES, Carlos, The Years With Laura Díaz, trans. Alfred Macadam, Farrar, Straus \& Giroux.

GARRETT, Garet, The Wild Wheel: The World of Henry Ford, New York, Pantheon Books, 1952.

GENAT, Robert, The American Car Dealership, Osceola, WI: MBI Publ. Co., 1999.

GOODRUM, Charles, DALRYMPLE, Advertising in America: The First 200 Years New York, Harry N. Abrams, Inc., 1990.

GRONER, Alex, The American Heritage History of American Business \& Industry, New York, American Heritage Publ. Co., 1972.

GUNTHER, John, Inside U.S.A., New York: Curtis Publishing, 1947. 
HAMILL, Pete, Diego Rivera, New York, Harry N. Abrams Inc.,1999.

HAUSER, Michael, WELDON, Marianne, Hudson's: Detroit's Legendary Department Store, Charleston, SC, Arcadia Publishing-“Images of America" Series, 2004.

HAYS, Samuel P., The Response to industrialism: 1885-1914, Chicago, University of Chicago Press, 1957.

HILLMAN, J. Re-Visioning Psychology, New York, Harper \& Row, 1977.

HOLLI, Melvin G, Reform in Detroit: Hazen S. Pingree and Urban Politics, New York, Oxford University Press, 1969.

HOFFER, Eric, The Passionate State of Mind and Other Aphorisms, New York, Perennnial LibraryHarper \& Row, 1968.

JACOBS, Jane, The Economy of Cities, New York, Vintage Books-Random House, 1969.

JARDIN, Anne, The First Henry Ford: A Study in Personality and Business Leadership, Cambridge, Mass., The MIT Press, 1970.

JEWISH INFLUENCES IN AMERICAN LIFE Volume III of "The International Jew The World's Foremost Problem". Being a reprint of a Third Selection from Articles Appearing in The Dearborn Independent, June 4, 1921- January 14, 1922, 24. No publisher listed; book spine labeled: "Dearborn"; book's preface is dated November 1921.

JEWISH TELEGRAPHIC AGENCY. Issues of: January 1, 1926, 2; April 16, 1926, 3; April 23, 1926, 4; April 28, 1926,1; May 3, 1926, 4. [JTA: founded in February 1917, London, by Jacob Landau in the manner of a newsletter as the Jewish Correspondence Bureau; Jewish Telegraphic Agency - Daily News Bulletin, Cable and Mail Despatches, 244 High Holborn, London W.C.1. ]

KENNEDY, David M., Freedom From Fear: The American People in Depression and War, 1929-1945, New York; Oxford University Press, 2005.

KINDEN, Diana L. ."Ben Shahn's New Deal Murals," in Susan Chevlowe, Ed., Common Man Mythic Vision: The Paintings of Ben Shahn, Princeton, N. J.: Princeton University Press-in association with the Jewish Museum, New York, 1998.

KRAFT, Barbara S., The Peace Ship: Henry Ford's Pacifist Adventures in the First World War, New York, Macmillan Publ. Co., Inc., 1978.

LACEY, Robert, Ford: The Men and the Machine, London, Pan Books Ltd. 1987.

LASKY, Victor, Never Complain, Never Explain, New York, R. Marek, Publs., 1981.

LATORRE, Guisela, Walls of Empowerment: Chicana/o Indigenist Murals of California, Austin, Texas, University of Texas Press, 2008.

LAUX, James, The European Automobile Industry, New York, Twayne Publs., 1992.

LEE, Albert, Henry Ford and The Jews, New York, Stein and Day Publs., 1980.

LEUCHTENBURG, William E., In the Shadow of FDR: From Harry Truman to Ronald Reagan, Ithaca, New York, Cornell University Press, 2nd edn.1989.

LEVIN, Jeffrey, “América Tropical”. Online article at Getty Museum web site newsletter "The Getty", 9.2, Summer 1994, Conservation at the Getty, http://www.getty.edu/conservation/ publications/newsletters/9_2/tropical.html

LEWIS, David. The Public Image of Henry Ford: An American Folk Hero and His Company, Detroit, Wayne State University Press, 1976. 
MALPAS, James. Realism, London, Tate Gallery Movements in Modern Art Series-South Sea International Press, 1997.

MARNHAM, Patrick, Dreaming With His Eyes Open-A Life of Diego Rivera, New York, Alfred A. Knopf, 1999.

MARTIN, Louis E, “Profiles: Detroit," in: Journal of Educational Sociology, Vol. 17, No. 5 (Jan., 1944) 279-288, q. 280.

MATUZ, Roger, Albert Kahn, Architect of Detroit, Detroit, Wayne State University Press, 2007).

MAYO, Elton, The Human Problems of an Industrial Civilization, Cambridge, Mass., Harvard University Press, 1933.

McDONALD, William F. Federal Relief Administration and the Arts, Athens, Ohio, Ohio State University Press, 1969.

NEVINS, Allan, HILL, Frank E., Ford: The Times, the Man, the Company. Volume 1, New York, Charles Scribner's Sons, 1954.

NEVINS, Allan, HILL, Frank E., Ford: Expansion and Challenge: 1915-1933. Volume 2, New York, Charles Scribner's Sons, 1957).

NEVINS, Allan, HILL, Frank E., Ford: Decline and Rebirth, 1933-1962. Volume 3, New York, Charles Scribner's Sons, 1963.

O'CONNOR, Francis V. ,"The Influence of Diego Rivera on the Arts of the United States during the 1930s and After," in: Diego Rivera: A Reterospective. Detroit: Detroit Institute of Arts-in association with W. W. Norton and Co., New York, 1986, exhibition catalog, under the direction of Ellen Sharp \& Linda Downs.

PASZTORY, Esther, Aztec Art, New York, Harry N. Abrams, Inc., Publ., 1983.

PEALE, Norman V., The Power of Positive Thinking, New York, Ballantine-Fawcett, 1992.

PECK, William H., The Detroit Institut of Arts: A Brief History, Detroit, Wayne State University Press, 1991.

QUAIFE, M. M., GLAZER, Sidney, Michigan From Primitive Wilderness to Industrial Commonwealth, New York, Prentice-Hall inc., 1948.

REMINISCENCES, FORD MOTOR COMPANY. In the Benson Ford research Center, Accession 65, exists a vast series of interviews done during the early 1950s, oral histories of prominent FMC employees in the days of Edsel and Henry Ford, rich with direct and indirect information about figures such as: Ablewhite, H. S.; Black, Fred Lee; Bricker, Mead L.; Bugas, John S.; Couzens, James; Davis, John R.; Hicks, Harold; Kanzler, Ernest; Lepine, A.J.; Miller, Logan; Wagner, Walter. The author has reviewed much, but far from all, of this valuable, in-house, alternately factual and highly gossipy material. See reference in “Appendix II: Recollections”, Ford R. Bryan, Henry's Lieutenants (1993), 301-321.

REZÉ, Michel, BOWEN, Ralph, Key Words in American Life: Understanding the United States, Paris, Armand Colin, 1998.

RICHARDS, William C., The Last Billionaire: Henry Ford, New York, Charles Scribner's Sons, 1948. RIVERA, Diego. My Art, My Life: An Autobiography, New York, Dover Publications Inc., 1991; orig. publ. 1960.

ROETHLISBERGE, F. J. \& W. J. Dickson. Management and the Worker, Cambridge, Harvard University Press, 1939. 
ROLLINS, Alfred B. Jr, Franklin D. Roosevelt and the Age of Action, New York, Laurel-Dell Publc. Co., 1960.

RUBENSTEIN, James M, Making and Selling Cars: Innovation and Change in the U.S. Automotive Industry, Baltimore, The Johns Hopkins University Press, 2001.

SEALANDER, Judith, "Philanthropy and Philanthropic Foundations," in Paul S. Boyer, ed., The Oxford Companion to United States History, New York, Oxford University Press, Oxford, 2001.

SHIRER, William L., The Rise and Fall of the Third Reich: A History of Nazi Germany, London: PanSewcker \& Warburg, Ltd., 1967.

SORENSEN, Charles E., WILLIAMSON, Samuel T., Forty Years With Ford, London, Jonathan Cape, 1957.

STEINBECK, John, The Grapes of Wrath, New York, Bantam, 1972; orig. publ. 1939.

STERNE, Margaret, The Passionate Eye: The Life of William R. Valentiner, Detroit, Wayne State University Press, 1980.

STEVENSON, D.K., American Life and Institutions, Stuttgart, Ernst Klett Schulbuchverlage GmbH, 1987.

SUSMAN, Warren I., Culture as History: The Transformation of American Society in the Twentieth Century, New York, Pantheon Books, 1984.

TARBELL, Ida, "Henry Ford-Early American," typescript file No. 2584.0034 (with hand corrections) in: Ida Tarbell Archives-Alleghency College, Pelletier Library of Allegheny College, Meadville, Pennsylvania, USA.

THOREAU, Henry D., The Writings of Henry David Thoreau, Boston, Houghton Mifflin, 1906.

TUCK, Jim, "Villa, Pancho," “http://www.anb.org/articles/20/20-01539.html”; American National Biography Online.

WERTHER, William B. Jr., DAVIS Keithe. Human resources and Personnel Management, New York, McGraw-Hill Bok Co., 1993.

WILENSKY, Harold L., LEBEAUX, Charles N., Industrial Society and Social Welfare, New York: The Free Press Inc., 1965.

WOLFE, Bertram D., The Fabulous Life of Diego Rivera, New York: Stein and Day, 1963.

WOOD, John C., WOOD, Michael, George Elton Mayo: Critical Evaluations in Business and Management, London, Taylor \& Francis, 2004.

WOODFORD Frank B., WOODFORD, Arthur M., All Our Yesterdays: A Brief History of Detroit, Detroit: Savoyard Book-Wayne State University Press, 1969.

\section{NOTES}

1. R. W. Apple Jr., New York Times, Late Edition, East Coast, NY, NY. Dec. 5, 1997, p. E.2:29.

2. My special gratitude to the fine staff at the Edsel \& Eleanor Ford House, Grosse Pointe Shores, Michigan, and to both The Benson Ford Research Center, Dearborn \& the Grosse Pointe Historical Society for making possible invaluable, on-site research about Edsel Bryant Ford's life \& times. See, respectively: "http://www.fordhouse.org/"; "http://www.hfmgv.org/research/index.aspx"; "http://www.gphistorical.org/". 
3. M. M. Quaife, Sidney Glazer, Michigan: from Primitive Wilderness to Industrial Commonwealth (New York: Prentice Hall, 1948) Ch. 26, "The Automobile and Highways," 286-96.

4. James M. Rubenstein, Making and Selling Cars: Innovation and Change in the U.S. Automotive Industry (Baltimore: The Johns Hopkins University Press, 2001) vii. Robert Genat, The American Car Dealership (Osceola, WI: MBI Publ. Co., 1999) 6. D. K. Stevenson, American Life and Institutions (Stuttgart: Ernst Klett Schulbuchverlage GmbH, 1987) 75. And U.S.Census Bureau, @: “https:// factfinder.census.gov/faces/nav/jsf/pages/index.xhtml"-by 2000: 221,475,000 registered motor vehicles; by 2006: 244,166,000.

5. For Detroit in the 1890s: Frank B. Woodford, Arthur M. Woodford, All Our Yesterdays: A Brief History of Detroit (Detroit: Savoyard Book-Wayne State University Press, 1969) Ch. 9, The Old Home Town, 213-232; Willis Frederick Dunbar, Michigan: A History of the Wolverine State (Grand Rapids, Michigan: W.B. Eerdmans Publ. Co., 1965) Ch. 19, "Michigan and the Automobile Age" 551-78; Frank Angelo, Yesterday's Detroit (Miami, Florida: E. A. Seemann Publ.Inc., 1974) Chs. 3 \& 4, 41-103.

6. For this type of cinematic figure in the period see: Douglas Fairbanks Jr., The Salad Days: An Autobiography (London: William Collins-Fontana, 1989; orig. publ. 1945) 66-67. Other examples: the character of John Fredersen played by Alfred Abel in Fritz Lang's Metropolis (1927) through Bob Cain played by Tyrone Power in Johnny Apollo (1940). As D. Fairbanks once said: "The man that's out to do something has to keep in high gear all the time." And, as with Fairbanks so with Edsel Ford, high gear drive was also dangerously exhausting. Farbanks' ironic last words were: "I never felt better in my life."

7. "EDSEL BRYANT FORD" [framed by a double role of typed asterisks], from the Collection of The Henry Ford, Benson Ford Research Center, Acc \# 1, Box 19, File 19-16, q. page 5.

8. William E. Leuchtenburg, In the Shadow of FDR: From Harry Truman to Ronald Reagan (Ithaca, New York; Cornell University Press, $2^{\text {nd }}$ edn.1989); Leuchtenburg quoting The New Republic.

9. The phrase "social concern" was first used widely in the USA in the sense of meaning "social concern for the well-being of children, the unemployed, etc." around 1904. See: OED and the Online Etmological Dictionary @; "http://www.etymonline.com/index.php? search=social+welfare\&searchmode=none"

10. Melvin G. Holli, Reform in Detroit: Hazen S. Pingree and Urban Politics (New York: Oxford University Press, 1969); “James Couzens [...] consciously groomed himself as a 'second Pingree”, 123-124.

11. Cited: Garett Garret, The Wild Wheel (New York: Pantheon Books, 1952) 58. Warren I. Susman, Culture as History: The Transformation of American Socciety in the Twentieth Century (New York: Pantheon Books, 1984) 136.

12. Charles Goodrum and Helmen Dalrymple, Advertising in America: The First 200 Years (New York: Harry N. Abrams, Inc., 1990) paragraph qs. respectively on p. 227, 228, 232.

13. Demon Rum-“The American Experience," with David McCullough; PBS; WGBH, Boston; WNET, New York; 1989.

14. John Morley, Voltaire (London: Macmillan \& Co., Ltd.: 1913; orig. publ. 1871) 6.

15. David Lewis, The Public Image of Henry Ford: An American Folk Hero \& His Company (Detroit: Wayne State University Press, 1976), index 573: "folk hero, man of people" listing for additional popularity polls about Henry Ford. Henry Ford voted as the greatest businessman of the 20th Century November 1, 1999: "Fortune selects Henry Ford Businessman of the Century"-but not manager.

16. So named and discovered by Admiral Richard Evelyn (1888-1957) whose polar expedition Edsel Ford personally financed. See Byrd's biography @: “http://www.freezeframe.ac.uk/ resources/biography-of-byrd-admiral-richard-evelyn"

17. "Corporations: Death \& Taxes," Time Magazine, June 7, 1943, 81-82, 84, 86. These figures shifted slightly over time. But the alloted proportions always remained about the same in Edsel Ford's lifetime. 
18. Henry Ford II as quoted in Robert Lacey, Ford: The Men and the Machine (London: Pan Books Ltd. 1987, orig. publ. 1986). Henry Ford II: 1945-1960, President, Ford Motor Company; 1960-79, FMC CEO; 1980, FMC Chairman. See: Victor Lasky, Never Complain, Never Explain (New York: R. Marek, Publs., 1981). For the Henry and Edsel Ford father-son relation, see: Anne Jardin, The First Henry Ford: A Study in Personality and Business Leadership (Cambridge, Mass.: The MIT Press, 1970). There is only a single, ramshackle biography of Edsel Ford to date: Henry Dominguez, Edsel: The Story of Henry Ford's Forgotten Son (Warrendale, Pa.: Society of Automotive Engineers, inc., 2002); plus the coffee table books written in time for the Ford Motor Company Centennial in 2003, such as Richard Bak, Henry and Edsel: The Creation of the Ford Empire (Hoboken, NJ: John Wiley \& Sons, Inc.: 2003). To date the single best short study of Edsel Ford (1893-1943) is Chapter XIV "Edsel" in: William C. Richard, The Last Billionaire: Henry Ford (New York: Charles Scribner's Sons, 1948) 202.

19. Henry Dominguez, Edsel Ford and E. T. Gregorie: The Remarkable Designs Team and Their Classic Fords of the 1930s and 1940s (Warrendale, Pa.: Society of Automotive Engineers, inc.: 1999); fine, definitive book on the subject.

20. For visual communication skills and image phobia see: Eugene S. Ferguson (1916-2004), Eugene S. Ferguson, 1977. "The Minds Eye: Non-Verbal Thought in Technology”. Science 1977 (4306): 827-36; J. Hillman, (1977) Re-Visioning Psychology (New York: Harper \& Row).

21. Ida Tarbell, "Henry Ford-Early American," typescript file No. 2584.0034 (with hand corrections) in: Ida Tarbell Archives-Allegheny College, Pelletier Library of Allegheny College, Meadville, Pennsylvania, 21.

22. S. N. Behrman, Duveen, The Intimate Portrait of a Fabulous Art Dealer (New York: Harmony Books, 1982; orig. publ. 1952) anecdote as related from Behrman's Duveen in Lacey, Ford, The Men \& The Machines (1986) 341-43.

23. Drawings affirmed in the Benson Ford Research Center collection, Dearborn, Michigan.

24. Edsel Ford-A. J. Lepine response to Miss A. H. Stanton, Art School of the Detroit Society of Arts and Crafts, Dec. 19, 1932; Acc. 572, Box 5, Folder 8.2, Family, The Benson Ford Research Center-The Henry Ford Museum.

25. See: Ford R. Bryan, Rouge Pictured In Its Prime (Dearborn: Ford Books-Wayne State University Press, 2003) Ch. 40 "Photographic Department," 246-51.

26. Editor of Ford News, business manager for Dearborn Independent, ran Ford news bureau in Mt. Clemens during Chicago Tribune trial, engineered creation of Ford's first radio station in 1920 (KDEN, Detroit; began transmission March 22, 1920), worked as investigative reporter for FMC, personnel manager for the FMC Engineering Laboratory, head of FMC Advertising Department from 1927-1943; head of FMC PR during early 1940s; 1944-1955 employed by American Motors; 1955: became professor of business administration at U. of M. See: Ford R. Bryan, Henry's Lieutenants (1993) 36-43.

27. For more on Charles Sheeler, see; Karen Lucic, Charles Sheeler and the Cult of the Machine (Cambridge, Massachusetts: Harvard University Press, 1993) "Essays in Art and Culture" series; Diana Murphy, Ed., Precisionism in America 1915-1941: Reordering Reality (New York: Harry N. Abrams, 1995); Eric de Chassey, Made in USA: L'art américain, 1908-1947 (Paris: Éditions de la Réunion des musées nationaux, Paris 2001); and online see "Charles Sheeler Art Gallery" Museum Syndicate website @: "http://www.museumsyndicate.com/artist.php?artist=516", retrieved: April 9, 2011.

28. Abraham A. Davidson, Early American Modernist Painting: 1910-1935 (New York: Harper \& Row, Publs., 1981) quote: 184; Ch. 5 "Precisionism," 182-228. Sheeler's work for World's Fairs and business expositions was far more accessible.

29. William C. Richard, The Last Billionaire: Henry Ford (New York: Charles Scribner's Sons, 1948) 202.

30. Allan Nevine and Frank Ernest Hill, Ford: Expansion and Challenge 1915-1933 (New York; Charles Scribner's Sons, 1957) 172. 
31. "Edsel Ford Tops the List of 10 Best-Dressed Men," Detroit News, November 29, 1935, reprint of anonymous AP article, same day. The International Best Dressed list officially began in 1940, established by Elezanor Lambert (1903-2003). See obituary: "Fashion impresario dies at 100" in: Town \& Country, January 1, 2004.

32. And Brummel supposedly said of George, Prince of Wales, when he first saw him: "Who's your fat friend?" See: 78 J.M. \& M. J. Cohen, The Penguin Dictionary of Quotations (London: Penguin, 1960) 78

33. See: David Farber, Sloan Rules: Alfred Sloan and the Triumph of General Motors (Chicago: University of Chicago Press, 2002) which is unfortunately more the history of a corporation and not the fascinating "corporate man" par excellence who was Alfred P. Sloan.

34. Personally witnessed in on-site interviews conducted by the author 2001-2006.

35. Eleanor Ford quote from: Hames A. Bridenstine, Eleanor \& Eleanor Ford House, Ed. Cynthia Jo Fogliatti (Woodlawn, Maryland: Wolk Press Inc.-Edsel and Eleanor Ford House, Grosse Pointe Shores, Michigan, 1988) 8. See Michigan state listing @: "http://www.mcgi.state.mi.us/hso/sites/ 9593.htm”. Jens Jensen 1860-1951. For Kahn, see: Roger Matuz, Albert Kahn, Architect of Detroit (Detroit: Wayne State University Press, 2007). For Jense Jensen (1860-1950), see: Julia Sniderman Bachrach, "Jens Jensen: Friend of the Native Landscape," in: Chicago Wilderness Magazine, Spring 2001. @: "http://chicagowildernessmag.org/issues/spring2001/jensjensen.html”

36. Winston Churchill, Time, Sept. 12, 1960.

37. When the area was prepared for the Ford house in 1926 an Indian princess was found buried there, a silver bracelet "the thickness of paper" encircled her forearm and a silver cross among her bones which was "six inches in height and bore an indecipherable inscription". From typed draft of The Grosse Pointe Guide, The Federal Writer's Project, circa. 1940, special collection: Grosse Pointe Public Central Library, 10 Kercheval Ave. at Fisher, Grosse Pointe, MI. Before it was Gaukler Pointe this outreach of land had three other names: Pointe a Guinolet; Tremble Point; Milk River Pointe.

38. Kenneth Clark, "The Worship of Nature," Chapter 11 in Clark's Civilization: A Personal View (London: Penguin, 1969) 188.

39. Henry David Thoreau, Walden (1854), in: The Writings of Henry David Thoreau (Boston: Houghton Mifflin, 1906) Vol. 2, 206-07. Potently strange is the fact that the car which was Edsel Ford's most personal creation was the Lincoln. Which was originally named after President Abraham Lincoln by Henry Leyland, yes. But look further behind the mask of the word. Lincoln? It is old English for "lake" or "pool": hence the city of Roman Lincoln; from: [L.] Lindon, Lindum. See: Lincol-official Guide (Lincoln, UK: J. W. Ruddock \& Sons Ltd.) 9. For E\&E Ford House online, see: "http:// www.fordhouse.org/; for Fair Lane: "farlan: http://www.henryfordestate.org/"

40. Alfred B. Rollins, Jr. Ed., Franklin D. Roosevelt and the Age of Action (New York: Laurel-Dell Publc. Co., 1960) 165, 72.

41. Michel Rezé, Ralph Bowen, Key Words in American Life: Understanding the United States (Paris: Armand Colin, 1998, $4^{\text {th }}$ edn.) 117.

42. J. L. Hudson created one of the three largest and most financially successful department stores that emerged in America with the advent of city shopping in the first half of the 20th century; was president of the Associated Charities of Detroit and "was a believer in the basic principle of the Democratic party, but in local affairs he gave his support" to causes, institutions, and individuals that " 'remembered those who were forgotten'." This same spirit continues to the present day in Detroit with the Hudson-Webber Foundation, 1943, which remains a significant source of social service grants for the metropolitan Detroit community. See: Michael Hauser, Marianne Weldon, Hudson's: Detroit's Legendary Department Store (Charleston, SC: Arcadia Publishing-"Images of America" series,2004); Vivian M. Baulch, "How J. L. Hudson changed the way we shop" at Detroit News online: http://info.detnews.com/history/story/index.cfm? id=29\&category=business-“"Rearview Mirror" series, 12/19/2002. 
43. This fact is specially visible in the records of the Ford Archives at the Benson Ford Research Center and throughout the various "Reminiscences" of contemporaneous Ford Motor Company employees. The Ford Foundation has been specially strong fostering education, progressive social science research favoring pluralism, and public TV.

44. NB: $85 \%$ in so far as these things can be measured, since there has always existed a certain amount of direct, one-on-one, or one-person-for-a-cause giving: the anonymous donor. See: Judith Sealander, "Philanthropy and Philanthropic Foundations," in: Paul S. Boyer, Ed. The Oxford Companion to United States History (Oxford University Press: Oxford, 2001); "Foundations, Endowed" in: Wayne Andrews, T. C. Cochran, Eds., Concise Dictionary of American History (New York: Charles Scribner's Sons, 1962); in Cochran, 374, note that a 1938 directory records 188 US foundations.

45. Barbara S. Kraft, The Peace Ship: Henry Ford's Pacifist Adventures in the First World War (New York: Macmillan Publ. Co., Inc., 1978).

46. See Website: "http://www.grit.com/history/" "Grit, America's family magazine since 1882, is dedicated to bringing readers good news. Grit focuses not on age or abilities, but on attitudetaking a positive approach to life. In each issue, we celebrate our readers' courage, dedication and determination to make a difference."

47. Ford R. Bryan, Beyond the Model T: The Other Ventures of Henry Ford (Detroit: Wayne State University Press, 1997, revised ed.) 102.

48. The Ford International Weekly The Dearborn Independent, Dearborn, Michigan, Jan. 11, 1919, masthead.

49. After five years in existence, FMC began its own combination Farmer's Almanac and travel magazine Ford Times (in 1908). By 1924 FMC had seven major publications, along with its wealth of automobile promotional material. By the prime days of Edsel Ford, the advertising division was supervised by the congenial jack-of-all-media trades Fred Lee Black (1891-1972), in close collaboration with Edsel Ford. See: “Fred Lee Black," Chapter 4 in Ford R. Bryan, Henry's Lieutenants (Detroit: Wayne State University Press, 1993) 37-43.

50. Ford R. Bryan, Beyond the Model T (1997) 103; Nevins and Hill, Ford: Expansion and Challenge: 1915-1933 (1957) Ch. 12 , "From Muscle Shoals to Anti-Semitism," 300-23. This kind of publication, with or without social or political content, has flourished from the colonial period to the present day-now in US print media from Forbes to Barbie Magazine. The common claim that Dearborn Independent reached a readership circulation of close to one million in the mid 1920s (when US population was apx. one hundred and six million) is factually unsubstantiated. Record show FMC dealers were constantly throwing away the DI copies they received.

51. In: The Ford International Weekly The Dearborn Independent, Dearborn, Michigan, May 22, 1920, front page article.

52. Jewish Influences in American Life. Volume III of "The International Jew The World's Foremost Problem". Being a reprint of a Third Selection from Articles Appearing in The Dearborn Independent June 4, 1921- January 14, 1922, 24. No publisher listed; book spine labeled: "Dearborn"; book's preface is dated November 1921.

53. Ibid., 75.

54. Ibid., 89.

55. Ibid., 117.

56. Ibid., 119.

57. Ibid., 224 .

58. The most recent authoritative study of Henry Ford and anti-Semitism is: Neil Baldwin, Henry Ford and the Jews: The Mass Production of Hate (New York: Public affairs-Perseus Books Group, 2001) -well done, yet simultaneously an indictment against capitalism. See also: Herman Bernstein, The History of a Lie: "The Protocols of the Wise Men of Zion" (New York: J. S. Ogilvie Publishing Co., 1921; repr. 1972). Which was a counterfeit document originally cooked up by the Russian secret 
police. They, in turn, had based their apparently serious work on the 1864 political satire by Maurice Joly, Dialogue in Hell Between Machiavelli and Montesquieu (Dialogue aux enfers entre Machiavel et Montesquieu).

59. William L. Shirer, The Rise and Fall of the Third Reich: A History of Nazi Germany (London: PanSewcker \& Warburg, Ltd., 1967; orig. publ. 1960).

60. The Reminiscences of Mr. Irving R. Bacon, Vol. II, 169, FMCOH, 1952.

61. Liebold fell apart under the pressure of the FMC situation by the early 1930s; disappeared one day and was thought to have committed suicide. He did not. But his standing in the company was never the same thereafter. The New York Times considered his career as Henry Ford's general secretary over by 1933; see: "Twenty Years With Ford," New York Times, March 1, 1933, 4. And: Ford R. Bryan, Henry's Lieutenants (1993) 172-73.

62. G. K. Chesterton (1874-1936), in his essay “Dickens and America” (1906) See etext @: "http:// www.lang.nagoya-u.ac.jp/ matsuoka/CD-Chesterton-CD.html"

63. Don Delillo, In Dallas (1988), pt. 2, Libra; originally published as: Don DeLillo “American Blood: A Journey through the Labyrinth of Dallas and JFK" in Rolling Stone, December 8, 1983.

64. Don Delillo, In Dallas (1988), pt. 2, Libra.

65. “Auto Men Join Ford in Guardian Trust,” The New York Times, June 9, 1925, 34.

66. First reported in a well known but poorly distributed newspaper the Jewish Telegraphic Agency - Daily News Bulletin, Cable and Mail Despatches, 244 High Holborn, London W.C.1. The Edsel Ford-Morris Friedberg meeting first received general, public attention in: "Ford's Own Inquiry Led to His Apology," The New York Times, July 12, 1927, 12-based on NYTimes research and Jewish Telegraphic Agency articles.

67. New York Times citing the Jewish Telegraphic Agency in: "Ford's Own Inquiry Led to His Apology," The New York Times, July 12, 1927, 12.

68. "Guardian Trust To Open," The New York Times, July 8, 1925, 28.

69. Sidney Bolkosky, Harmony \& Dissonance: Voices of Jewish Identity in Detroit, 1914-1967 (Detroit: Wayne State University Press, 1991) 86.

70. Dr. Leo M. Franklin, "Ford The Suppliant versus Ford The Sinner," Detroit Jewish Chronicle, July 27, 1927.

71. Some Untold Tales of Detroit and Detroiters [Unpublished, limited-access restricted manuscript, 1947]; Detroit-Bloomfield Hills, Temple Beth El-Franklin Archives. Leo Franklin: 1870-1948; Rabbi Temple Beth El, Detroit 1899-1941.

72. Sidney Bolkosky, Harmony and Dissonance (1991) 84-85.

73. This debate was sometimes divided along lines of American German Jewish (against Zionism) versus American Eastern European Jewish (for Zionism). Zionism itself in America was then divided among two main camps and leaders: Chaim Weizmann (1874-1952) and Justice Louis Brandeis (1856-1941). Unquestionably Brandeis' eloquent arguments which related Zionism to America's founding colonies and "hardy pioneers" gave the movement a certain respect. Also, Brandeis belonged to a generation in which professional members of the American Jewish community had notably advanced in America's most esteemed institutions; by 1922 thirteen per cent of Harvard's graduating class "professed Judaism" Jews were thus gradually entering into the circulation of elites in the United States. Qs; respectively: "Mr. Justice Brandeis Memorandum," Jewish Telegraphic Agency, October 13, 1920, 2; Jewish Telegraphic Agency , April 23, 1926, 4 .

74. See: Jewish Telegraphic Agency issues of: January 1, 1926, 2; April 16, 1926, 3; April 28, 1926,1; May 3, 1926, 4 .

75. New York Times citing the Jewish Telegraphic Agency in: "Ford's Own Inquiry Led to His Apology," The New York Times, July 12, 1927, 12.

76. Albert Lee, Henry Ford and The Jews (New York: Stein and Day Publs., 1980) 135. 
77. Dr. Solomon B. Freehof, “Zionism and the American Jew," lecture, Sunday March 13, 1927, Chicago Illinois; published under the auspices of the K.A.M. Men's Club, 14.

78. A classic case exists in Shakespeare's Hamlet. The main character thinks too much. But he has two foils who enhance the equilibrium he needs to develop in order to succeed. On one side Hamlet has his friend Laertes, a flamboyant man of action, and on the other Hamlet has his friend Horatio, a man of restrained intelligence.

79. Ford R. Bryan, Clara: Mrs. Henry Ford (Dearborn, Michigan: Ford Books, 2001) 12, passim.

80. Growing old is inevitable, growing up is optional-as the American saying goes. Although he was quite wealthy, Henry Ford insisted he wasn't in it for the money-as attested by various interviews throughout his life and also by his quirky, catastrophic financial mismanagement (e.g., in the change from the Model T to the Model A).

81. Benson Ford Research Center, Harold Hicks "Reminiscence"; see: Reminicences collection, Ford Motor Company, in the Benson Ford research Center, Accession 65; see: online @: "http:// www.hfmgv.org/search.aspx"

82. Louis-Ferdinand Celine, Journey To the End of the Night, trans. John H. P. Marks (New York: New Directions Publ. Co., 1960; orig. publ. 1932) 224, 225.

83. Also notable was the Chrysler Tank Arsenal at Detroit, the General Motors Tank arsenal near Flint, and Ludington's top-rated chemical plant. All WWII production statistics here from M. M. Quaife \& Sidney Glazer, Michigan From Primitive Wilderness to Industrial Commonwealth (New York: Prenrtice-Hall inc., 1948) 360.

84. Which was "one of several blue-collar, ethnic sitcoms popular in the" era which "allowed for occasional barbs directed at the frustrations of factory employment and at the pretensions of the upper classes". See: "The Life of Riley:U.S. Situation Comedy" at The Museum of Broadcast Communications website, @: "http://www.museum.tv/archives/etv/L/htmlL/lifeofriley/ lifeofriley.htm"

85. "Mind of the Middle West", Chapter 18 of John Gunther's Inside U.S.A. (New York: Curtis Publishing, 1947; 1997 Book-of-the-Month Club Rpt.) 276.

86. "The People Crunch," The Economist, Vol. 390, No. 8614, Jan.17, 2009, 51-53. In the United States, Pittsburg was another great industrial town of the same generation but not the same problems, because it never had to reckon with the extreme diversity of human groups and the singular economic forces which characterized Detroit. Nearby Chicago had its own history of economic down turns and social unrest, but not like Detroit. Neither Pittsburgh nor Chicago ever unravelled at the seams like Detroit. They never took its gamble.

87. As opposed to a preformation or homonuculus idea of the city-that is the development of an embryo of what is already there. See: Jane Jacobs, The Economy of Cities (New York: Vintage BooksRandom House, 1969), q. 129.

88. See: Wyandot language dictionary. Wyandot were the Hurons of the Detroit area. @: "http:// www.wyandot.org/lang1.html"

89. Although Rivera was constantly filmed at work and regularly accompanied by a FMC photographer, and Edsel Ford regularly visited Rivera at work and invited he and his wife Frida Kahlo to his home, to date not a single photograph of Edsel Ford and Diego Rivera together has been located.

90. Michigan: A Guide to the Wolverine State, compiled by workers of the Writer's Program of the Works Project Administration in the State of Michigan (Washington: Library of Congress, 1941, 1971 rpt.) 232.

91. The foreign brands were soon even made in the USA, but not in Detroit. Volkswagen started producing in the USA in 1978. Toyota started making cars Stateside in 1984. Nissan Motors established its first US assembly operations in the early 1980s. See: James Laux, The European Automobile Industry (New York: Twayne, 1992). 
92. Louis E. Martin, "Profiles: Detroit," in: Journal of Educational Sociology, Vol. 17, No. 5 (Jan., 1944) 279-88, q. 280.

93. “Side Remarks," Detroit Free Press, Saturday, December 30, 1893, 4; author's italics.

94. Bertram Wolfe, The Fabulous Life of Diego Rivera (New York: Stein \& Day, 1963) $457 \mathrm{ff}$.

95. Patrick Marnham, Dreaming With His Eyes Open-A Life of Diego Rivera (New York: Alfred A. Knopf, 1999) 100.

96. The term negative capability is used in literary and artistic criticism as well as psychology; means a creative individual's unusually powerful ability for open-mindedness, empathy, receptivity for the personalities and qualities of other people; orig. a theory of British Romantic poet John Keats as expressed in a December 28, 1817, letter to his brothers. In other words, one negates one's own personality to positively become like another person.

97. Diego Rivera, My Art, My Life: An Autobiography (with Gladys March) 22

98. Aldous Huxley, Brave New World Revisited (New York: Bantam Books, 1960, orig. Publ. 1958), Ch. IV "Propaganda in a Democratic Society" 30-31, both quotes.

99. See, e.g., David M. Kennedy, Freedom From Fear: The American People in Depression and War, 1929-1945 (New York; Oxford University Press, 2005) 255. Bruce I. Bustard, A New Deal for the Arts (Seattle: University of Washington Press, 1997) 86.

100. Diego Rivera, My Art, My Life $(1991 ; 1960) 111$.

101. See: Elliott Roosevelt, F. D. R.-His Personal Letters 1905-1928 (New York: Duell, Sloan and Pearce, 1948) 634-35. Edsel and Eleanor Ford House oral history: Tom Loughlin's daughter (Loughlin: security head for Edsel and Eleanor Ford until his 1971 death); noted Loughlin: "met FDR in Seal Harbor, Maine, when Roosevelt's yacht came into the harbor [...] no [specific] date attached to that, or any other information." Courtesy: Mr. David Janssen, VP, Edsel and Eleanor Ford House; Email: 15 Oct 2004.

102. Diego Rivera, My Art, My Life $(1991 ; 1960) 112$.

103. The two definitive; first-hand witnesses of the Detroit Industry Murals creations are: Margaret Sterne, The Passionate Eye; the Life of William R. Valentiner (Detroit: Wayne state University Press, 1980), Ch. 1X, "Acquisitions, Tribulations, and the Diego Rivera Murals, 1930-1932," 178-204; and the fanciful record in: Diego Rivera, My Art, My Life: An Autobiography (with Gladys March) (New York: Dover Publications Inc., 1960) “A Visit With Henry Ford" and "The Battle of Detroit" 111-15. NB: Rivera notoriously changed details in various tellings of this event; his own writings are closer to "magical realism" than straight-forward fact.

104. Diego Rivera, My Art, My Life $(1991 ; 1960) 116 ?$

105. Eric Hoffer, The Passionate State of Mind and other aphorisms (New York: Perennnial LibraryHarper \& Row, 1968, orig. publ. 1954) 97.

106. A widget which otherwise looms so formidable in American life and legend. "To George F. Babbitt [...] his motor-car was poetry and tragedy, love and heroism," Sinclair Lewis, Babbitt, 1922.

107. Bruce I. Bustard, A New Deal for the Arts (Washington, D. C.: National Archives and Records Administration, 1997).

108. John Steinbeck, The Grapes of Wrath (New York: Bantam, 1972; orig. publ. 1939) 463; movie: The Grapes of Wrath, dir. John Ford, with Henry Fonda, Jane Darwell, John Carradine, TCF (Darryl Zanuck, Nunnally Johnson) 1940.

109. See Paul Strand's March-April 1940 comparison between the two online at the New Deal Network site @: "http://newdeal.feri.org/search_details.cfm?link=http://newdeal.feri.org/pn/ pn3440.htm".

110. See, e.g., IMDB's top rated 1940s films @: “http://www.imdb.com/chart/1940s”.

111. Roger Ebert, The Grapes of Wrath (1940), March 31, 2002, review, @: “ http:// rogerebert.suntimes.com/apps/pbcs". 
112. The actual text on the wall, on the top white sheet of paper Valentiner holds before him on the south wall, reads: "These frescoes, painted between July 25, 1932, and March 13, 1933, while Dr. William Valentiner was director of the Art Institute, are the gift to the City of Detroit of Mr. Edsel B. Ford, president of the Arts Commission." Valentiner was crucial as go-between, agent, connoisseur, museum factotum, and chronicler of art history; but otherwise for the DIA's DIMs of secondary importance. Valentiner (1880-1958) was extraordinary, of a genuine German Romantic, aesthete mold like a Thomas Mann (1875-1955) character of The Magic Mountain generation.

113. Carlos Castillo \& Otto F. Bond, The University of Chicago Spanish Dictionary (New York: Pocket Books-Simon \& Schuster, 1977, 3rd edn.) 178.

114. William Valentiner (1880-1958), Detroit Institute of Arts director, 1924-1945, as quoted in: Margaret Sterne, The Passionate Eye: The Life of William R. Valentiner (Detroit: Wayne State University Press, 1980) 202.

115. Diego Rivera, My Art, My Life: An Autobiography (with Gladys March) (New York: Dover Publications Inc., 1991; orig. publ. 1960) 124. The Rockefeller-Rivera debacle is also a center piece of the exhilarating film The Cradle Will Rock (dir. Tim Robbins, with Ruben Blades, Susan Sarendon, John Cusak, prod. T. Robbins, 1999).

116. Rockefeller Jr. was infinitely more cold, dogmatic and insensitive to art and artists than comprehensive Edsel Ford (a not uncommon fate in businessmen). This was also evident in the difficulty J. D. Rockefeller Jr. had understanding and accepting what his wife Abbey Rockefeller did with the Museum of Modern Art in New York City.

117. Diego Rivera, My Art, My Life $(1991 ; 1960) 122$.

118. Villa as quoted in: Jim Tuck, "Villa, Pancho," "http://www.anb.org/articles/ 20/20-01539.html"; American National Biography Online. Francisco Madero (1873-1913): urbane son of a wealthy landowning family, educated in Paris and California, revolutionary and president of Mexico: 1911-1913; supported by Villa; assassinated and martyred as an embodiment of Mexican democracy.

119. Diego Rivera, My Art, My Life $(1991 ; 1960)$ 122. Margaret Sterne, The Passionate Eye: The Life of William R. Valentiner. Detroit: Wayne State University Press, 1980.

120. D. H. Lawrence, Studies in Classic American Literature (London: Penguin, 1977; orig. publ. 1923) 181.

121. D. H. Lawrence, Studies in Classic American Literature $(1977 ; 1923) 181$.

122. W. C. Richards, The Last Billionaire, 319.

123. Bertram D. Wolfe, The Fabulous Life of Diego Rivera (New York: Stein and Day, 1963) 311; they opened for public viewing on March 13, 1933.

124. Detroit Evening Times, March 21, 1933, cited: Bertram D. Wolfe, The Fabulous Life of Diego Rivera (1963) 312.

125. Diego Rivera, My Art, My Life $(1991 ; 1960)$ 121-22.

126. Diego Rivera, My Art, My Life $(1991 ; 1960) 118$.

127. As cited in: Bertram D. Wolfe, The Fabulous Life of Diego Rivera (New York: Stein and Day, 1963) 313. Brewing here was an American version of the infamous exhibition in Nazi Germany "Entartete Kunst" (Degenerate Art) inaugurated by Father Coughlin's supporter Joseph Goebbels in Munich in July 1937. See: Schulamith Behr, Expressionism (London: Tate Publishing, 1999) 73-74.

128. See this center piece @: "http://www.abcgallery.com/s/siqueiros/siqueiros44.html”. Olvera Street is also L.A.'s oldest street, named after Agustin Olvera (d. 1876), Mexican lawyer and government official, who bridged the era between Mexican and U.S. ownership of California. See: Guisela Latorre, Walls of Empowerment: Chicana/o Indigenist Murals of California (Austin, Texas: University of Texas Press, 2008), $38 \mathrm{ff}$.

129. See: Jeffrey Levin, "América Tropical", online at the Getty Museum web site newsletter "The Getty" 9.2, Summer 1994, (Conservation at the Getty): @: "http://www.getty.edu/conservation/ publications/newsletters/9_2/tropical.html" and on-going coverage by the L. A. Times. Plus: 
Christopher Knight, "Siqueiros mural 'America Tropical' to reopen in 2012-13. Maybe," Los Angeles Times, September 9, 2010; @ “http://latimesblogs.latimes.com/culturemonster/2010/09/ siqueiros-mural-america-tropical-to-reopen-in-2012-13-maybe.html”.

130. Diego Rivera, My Art, My Life $(1991 ; 1960) 116$.

131. Valentiner, as cited in: Margaret Sterne, The Passionate Eye: The Life of William R. Valentiner (Detroit: Wayne State University Press, 1980) 196-97, Ch. IX, “Acquisitions, Tribulations, and the Diego Rivera Murals, 1930-1932," 179-203.

132. As defined by Aldous Huxley (1894-1963), Antonio Gramsci (1891-1937), and as prefigured in Thomas Carlyle's prophetic essay “Signs of the Times", Edinburgh Review, No.98, 1829.

133. Reinhard Bendix, Work and Authority in Industry: Ideologies of Management in the Course of Industrialization (New York: Harper \& Row, 1963; orig. publ. 1956) 435.

134. Peter Firchow, Bernfried Nugel, Eds, Aldous Huxley: Modern Satirical Novelist of Ideas (Berlin: LIT Verlag Münster-Hamburg-Berlin-Wien-London-Zürich, 2006) 209. First US edition of Brave New World was New York, Doubleday, Doran \& Co., 1932.

135. Esther Pasztory, Aztec Art (New York: Harry N. Abrams, Inc., Publ., 1983) 160.

136. For an excellent expression of this see the Reverand Henry Ward Beecher's sermon of November 23, 1872 in Henry Ward Beecher, The Sermons of Henry Ward Beecher in Plymouth Church Brooklyn from Verbatim Reports by T. J. Ellinwood, "Plymouth Pulpit," Ninth Series (New York: J. B. Ford Publ., 1874) 225-26.

137. Carlos Fuentes, The Years With Laura Díaz, Ch. One, "Detroit 1999," trans. Alfred Macadam, Farrar, Straus \& Giroux; online at: "http://www.nytimes.com/books /first/f/fuentesyears.html".

138. Norman Vincent Peale, The Power of Positive Thinking (New York: Ballantine-Fawcett, 1992, orig. publ. 1952) 70. Prefiguring Peale in industrial relations of the 1930s was the new Human Relations Movement lead by Elton Mayo (1880-1949), Harvard Business School professor of industrial research. Happiness and cooperation come naturally, argued Mayo, once workers identify with group interests and welfare. Happiness and a sense of individual security result from "effective collaboration in a restructured range of activity", and thus secure social order and discipline. John Cunningham Wood, Michael Wood, George Elton Mayo: critical evaluations in business and management (London: Taylor \& Francis, 2004) 93, 111-12. Elton Mayo, The Human Problems of an Industrial Civilization (Cambridge, Mass.: Harvard University Press, 1933).

139. Noted as so labeled by Rivera in Linda Bank Downs, The Detroit Industry Murals (New York: Detroit Institute of Arts-W. W. Norton \& Co., 1999) 123.

140. James Malpas, Realism (London: Tate Gallery Movements in Modern Art Series-South Sea International Press Ltd, 1997) 7.

141. James Malpas, Realism (London: Tate Gallery-South Sea International Press, 1997) 49.

142. James Malpas, Realism (1997) 49.

143. Abraham Lincoln, “Annual message to Congress," December 3, 1861, in: The Collected Works of Abraham Lincoln, Ed. Roy P. Basler, vol. 5, p. 52 (1953).

144. Who Rivera wanted to put in place of Lenin in the demolished Rockefeller Center fresco.

145. Edith de Bonnafos ["On the Art of Diego Rivera"], "Grandes Choses, il ne faut pas être audessus des Hommes: il faut être avec eux" (Montesquieu" in: Diego Rivera, No;91 in Hachette series "Chefs d'œuvres de l'art" (Paris: Hachette, 1968) 7.

146. Factory section on YouTube @: "http://www.youtube.com/watch?v=nlZDNf_12sk"

147. William F. McDonald, Federal Relief Administration and the Arts (Athens, OH: Ohio State University Press, 1969) 354-55.

148. William F. McDonald, Federal Relief Administration and the Arts (1969) 355.

149. See, e.g., the coverage on murals in: Bruce I. Bustard, A New Deal For The Arts (Seattle: The University of Washington Press-in association with National Archives \& Record Adminstration, 1997); Diana L. LKinden, “Ben Shahn's New Deal Murals," in: Susan Chevlowe, Ed., Common Man 
Mythic Vision: The Paintings of Ben Shahn (Princeton, NJ: Princeton University Press-in association with the Jewish Museum, New York, 1998) 36-65; Francis V. O'Connor, "The Influence of Diego Rivera on the Arts of the United States during the 1930s and After," in: Diego Rivera: A Reterospective (Detroit: Detroit Institute of Arts-in association with W. W. Norton and Co., New York, 1986) exhibition catalog, under the direction of Ellen Sharp \& Linda Downs.

150. F. D. Roosevelt's address on the tenth anniversary of The Museum of Modern Art, as printed in the New York Herald Tribune, May 11, 1939.

\section{AUTHOR}

\section{JOHN DEAN}

University of Versailles 